\title{
THE BIACR SWANS
}

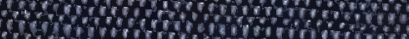




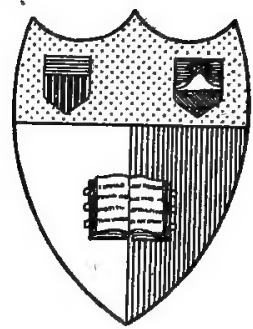

\section{A̛ne 其ark State Gallege of Aurirulture} At Garnell Altuîuergity Jthara, 村. 糸.

\section{Zihrary}




\section{Cornell University Library}

PS 3537.A624B6

The black swans, and other friends indoo

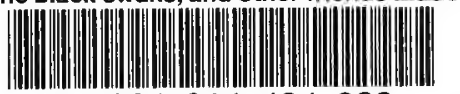

3 1924014494938 тапп 


\section{Cornell University Library}

The original of this book is in the Cornell University Library.

There are no known copyright restrictions in the United States on the use of the text.

http://www.archive.org/details/cu31924014494938 


The Black Swans 




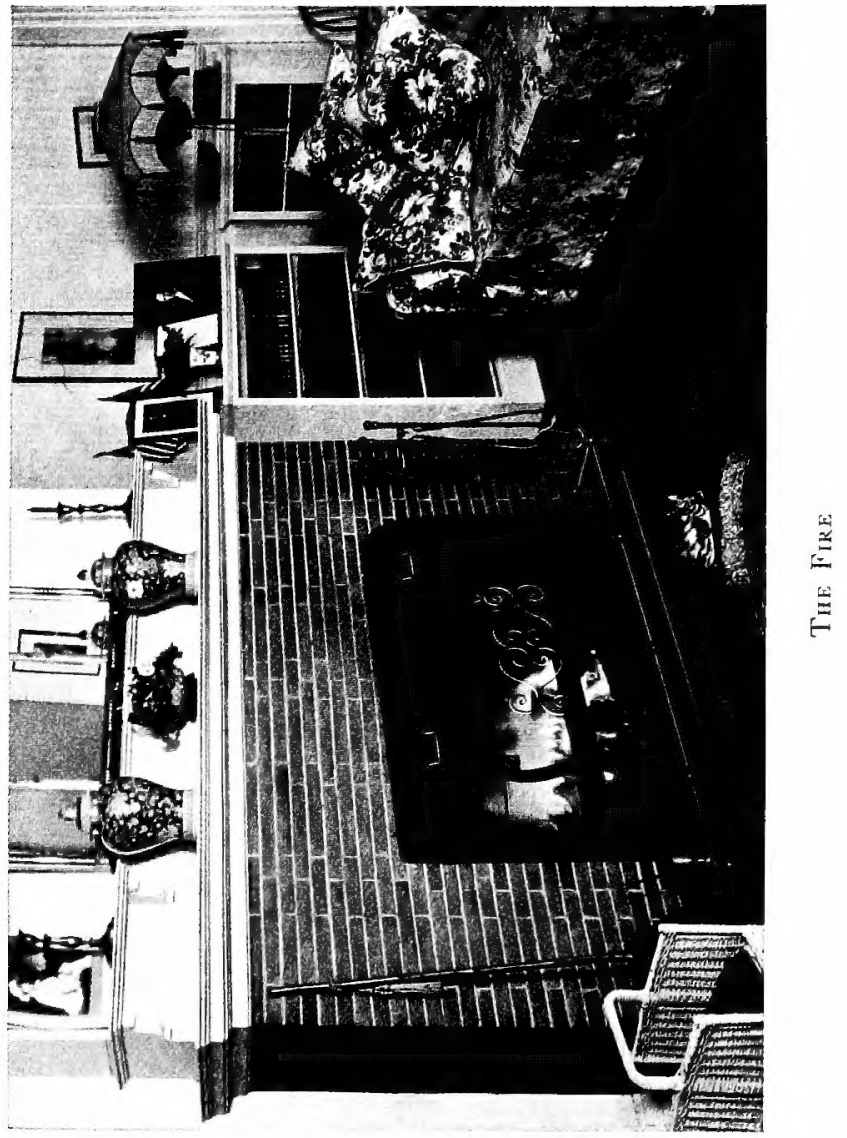




\title{
The Black Swans
}

\author{
And Other Friends \\ Indoors and Out
}

By

Alvin Howard Sanders

Author of "The Road to Dumbiedykes,"

"At the Sign of the Stock Yard Inn."

Editor "The Breeder's Gazette."

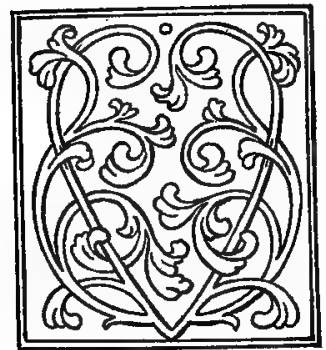

Chicago

Breeder's Gazette Print

I 9 I 8 
Copyright, 1918

Sanders Publishing Company

All Rights Reserved 


\section{Introduction}

7 HE kindly reception given a little 1 book of sketches published two years ago under the title "The Road to Dumbiedykes" must be my only apology for complying with various requests from perhaps over-partial friends to prepare a companion volume in similar vein. The first was sent forth with more or less trepidation because such work is entirely at variance with the weightier matters that have for so many years occupied my close attention, and I a m equally in doubt as to whether or not the publishers are justified in permitting "The Black Swans" to see the light.

Needless to say both are merely "byproducts" of idle hours; of days spent primarily in quest of rest and relaxation; just rambling thoughts jotted down from time to time with no particular regard to orderly sequence, and with slight expectation that they will be taken very seriously. Their preparation is of course merely a casual manifestation of an ever ready response to the lure of the out-of-doors.

DUMBIEDYKes, The Author October I5, I9I 8 
“THougr for me no focks unnumbered, Grazing Gallia's pastures fair

Breathe heavily beneatb their swelling fleeces, Still I at least am free from care."

- Horace. 


\section{Contents}

CHAPTER

I. The Building of the

Nest . . . . . . . I

II. Behind the Backlog . I5

III. Half-Hours with Mer-

CURY AND VULCAN . . 3I

IV. Low Tides . . . . . 45

V. The Case of Kate . . 6I

VI. SMOKe OF the H-F BaR . 73

VII. Told in the Firelight . 89

VIII. "TICK-Tock" TALK . . IO3

IX. An August Night . . I I23

X. Socks and Flocks . . I 137

XI. The Pig in a Poke. . I49

XII. A Pumpin and a Prince I6I

XIII. The Flames that

Clarify . . . . . . . I79

XIV. A Farewell "Hike" . I89

XV. "TAPS"....... . 203 



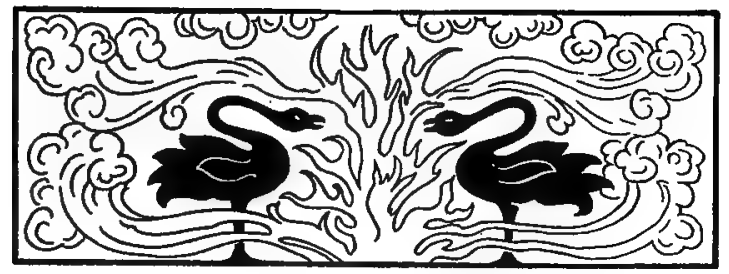

\section{THE BLACK SWANS}

\section{CHAPTER I \\ The Building of the Nest}

THE world goes motoring heedless 1 by along a narrow country road that disappears among the trees. The vine-clad walls, the moss-green roof and sheltering oaks accomplish their intended purpose. The little whitearched gateway too is camouflaged by all-embracing shrubbery. But those who care and enter understandingly are welcome as the flowers that greet them lovingly as they pass within. And if by chance you wander by along a walk that passes on the opposite, the sunset side, an ivy-posted snowwhite pergola projected from the 


\section{The Black Swans}

greenery will lead you through the hedge-row to the door. Those burroak trees that overhang the eaves and guard on either side the entrance-way, God planted many years ago and waited. Sooner or later some one was certain to look at them and comprehend. And when we found them first I knew at once a mile-stone in a journey had been set. And so one day there came into the world our Dumbiedykes.

Just a little temple in a grove! Just a little shrine at which the deities that rule the out-of-doors are worshipped. Just a little place to call a country home! Just a little port of friendly call for those who have it on their chart! And is that not enough?

No acres broad extending far afield. No great red barns nor cattle-yards nor granaries; no silos, plows nor harvesters; no retinue of help nor tenant cottages! Why should we covet these? For on the outside have we 


\section{The Building of the Nest}

not the sunshine and the storms, the song birds and the stars; and have we not within the black swans with their wings of fire, the friendly old four-posted clock and books that live through all the generations?

I had told the architect first of all to build for us a good big generous fireplace with a chimney that would not fail to draw; and then put walls around it surmounted by a wide, low roof with overhanging eaves. You will see the point. I wanted to hear in comfort by the fire the rain drops dripping all around outside. But if you are ever called upon, as I was after the little patch of woodland in the rough was bought, to plan the house intended for a snug retreat from city sights and sounds, do not make this one mistake. Let the women-folk in on it early. If you don't you will have to do so at some little extra cost later on, as I did. They know a lot more than you do-or they think 


\section{The Black Swans}

they do - which in all arguments affecting domestic arrangements comes to the same thing, and usually they will be right and you will be wrong. So compromise matters right at the outset by doing just what they tell you to do; and yet in giving them the reins in this building business in respect to certain things in which they have a natural, and it seems an inherently intelligent interest, if you have a hobby of your own just insist upon riding it yourself while they are astride their own.

It so happens that my own special obsession in this home-making proposition is an open fire, and in this particular case the builder to my mind has scored success complete. It is the best fireplace I know. It is broad and deep and lets me do the smoking; and I will also add that the creator of our little design did really well in other details. The outside elevation is generally well regarded. The 


\section{The Building of the Nest}

generous porch, the living room, the stairs and sleeping quarters are not seriously faulted. The dining room was, and is yet, small, too small for general entertaining, but there are but two of us left now, and with the lapse of years our visitors seem to be narrowing down to just a few of those we love the best, so that the very coziness of the little nook contributes perhaps whatever charm it may possess. The door that opens towards the little garden on the east is guarded by mock oranges now reaching upward to the roof, laden each May with heavily scented bloom; a favored leafy canopy for nesting birds. Along the casements on the south rare hollyhocks send up each year the brilliant stalks so loved by busy "bumble" bees.

The trouble was the architect and myself both forgot about the kitchen. That is, I forgot it altogether, and he very nearly. He did "come to" long 


\section{The Black Swans}

enough, however, to provide a two-byfour corner somewhere about the premises which I remember was labeled on the blue print "Kitchen." Billy was in the hands of nurses at the time and more interested in getting well than in architectural drawings, and as we wanted first of all a place where she could soon enjoy the sun and air during a prospectively extended convalescence, I gave the word and ground was broken for the big fireplace, kitchenette and all. Needless to say the original culinary department in later years was converted into a generous butler's pantry, and a sure-enough kitchen added, where Mary now presides with just pride in commodious surroundings and sings, as she works, the song that first made Chauncey Olcott's reputation.

It takes two hearts to make a home. Architecturally speaking the kitchen is one, the open fire the other. Both of these now work as one at Dumbie- 


\section{The Building of the Nest}

dykes, with a common purpose-the comfort of those they serve.

The chimney breast that forms the setting for the fires I love so well was built of the long flat two-bytwelve inch mottled Roman bricks. It is a trifle over four feet high and seven and a half in width. The fireplace proper is four by two feet six. The interior depth two feet. The firefloor, of the same brick, set on edge, extends outward sixteen inches to form the hearth. The shelf at the top is a twelve-inch piece of oak with plain moulding below, without carving or ornamentation of any sort. The proportions are believed to be good, and the general effect is one of solidity and practical utility for the purpose intended. The andirons sweep forward first, then back and out again in graceful curves. The fender is of iron and a big steel screen arrests the sparks. And then, of course, tongs, poker, shovel, and a little broom. Just 


\section{The Black Swans}

why the shovel I do not know. Perhaps some one uses it. I never do. The ash-dump relegates the shovel, I should say, to the limbo of the dinosaurian. Anyhow, I don't want the ashes all removed.

Each newly lighted fire should be builded always on the memories of the last.

And now about the swans, our two black swans, that long have made their home, and have contributed in no small degree to the making of the home, at Dumbiedykes. We have never had detailed information as to their remote origin; nor can I say that we have had any special curiosity upon that score. Notwithstanding their unusual character, it has sufficed to know that they came to us with the first building of the fire upon our hearth and still remain to minister unceasingly and most effectually to our peace of mind and bodily comfort; and the darker the day or the colder 


\section{The Building of the Nest}

the world outside the more certain their ready response to our appeal. Furthermore, unlike those other fabled ornithological wonders, the great rocs told of in the "Arabian Nights," which only appeared when sent for, these swans are ever with us and are indeed at no time parted from one another. In fact, they are inseparable, useless each without the other. Year after year they stand patiently side by side waiting to do our bidding, and the value of the service they have rendered, and are yet to render, who can calculate? Assuredly I cannot.

Men who are supposed to know about such things tell me that these birds probably came originally from the North. They have even gone so far as to assert that in all human probability they hark back to a primeval home located, say about latitude $47^{\circ}$ $40^{\prime \prime}$ north and longitude $93^{\circ} 20^{\prime \prime}$ west of Greenwich, and if you will turn to your map you will see that this fixes 


\section{The Black Swans}

the earlier habitat of these mystic swans of ours somewhere in the iron environment of the Mesaba Hills.

They sing not, neither do they swim; they eat not, neither do they drink; they fly not, neither do they walk, these swans mysterious; but they have a certain wondrous, priceless power which is never invoked in vain. At a given signal they appear with flaming wings and you have only to resign yourself to the magic spell of the light they radiate on such occasions to leave your cares at once behind. You may then be borne aloft and far away, across immeasurable heights and depths, over mountains, lakes and seas, over fields and forests, back into the remotest reaches of the past, or forward into the illimitable vistas of the future. Such is the boon bestowed on those who really know and understand these black-swan andirons of our open fire. They wait only the striking of the tiny match that lights 


\section{The Building of the Nest}

the forest-born burden on their backs to bear you where your fancy leads; and presently the old clock in the corner there will strike, and bring your fireside travels to a happy end.

I am not altogether certain, even after the lapse of many years of close companionship with these two faithful friends, as to which has really contributed most to the sum total of life, the fireplace or the clock. Close analysis of the psychology of the situation would, I fancy, assign first place in our affections to the flame upon the hearth, but through the darker days and frosty nights of the early spring and fall, when the glowing logs have first put one in the proper mood, there would still be something lacking but for the old clock's soft-voiced measured marking of the hours.

It is not one of those massively grand affairs with golden chimes and shining brass securely boxed in a mahogany mausoleum with a time-lock on the 


\section{The Black Swans}

plate-glass door. We have one of those too, in town, a very ornamental piece of furniture, to be sure, but no intimate of mine. It's too infernally exclusive. You can't get near it. A fine Swiss watch kept in a fire-and-burglarproof safe would be quite as sociable. Not so this dear old-fashioned thing that came to live with us at Dumbiedykes. You have seen clocks like it. Our grandfathers knew them well. We ought to know them better. Simple works, mounted on a shelf behind a dial. Big, square, iron weights operated by chain and pulley. A long wooden pendulum with its metal disc swaying lazily back and forth between four open posts, some seven feet in height. Nothing comes between you and itself. It is there, alive, close to you.

I am not sure but it has altogether the most agreeable personality of any member of the household. Its poise is so perfect, its voice is never raised in anger nor suppressed in sullen 


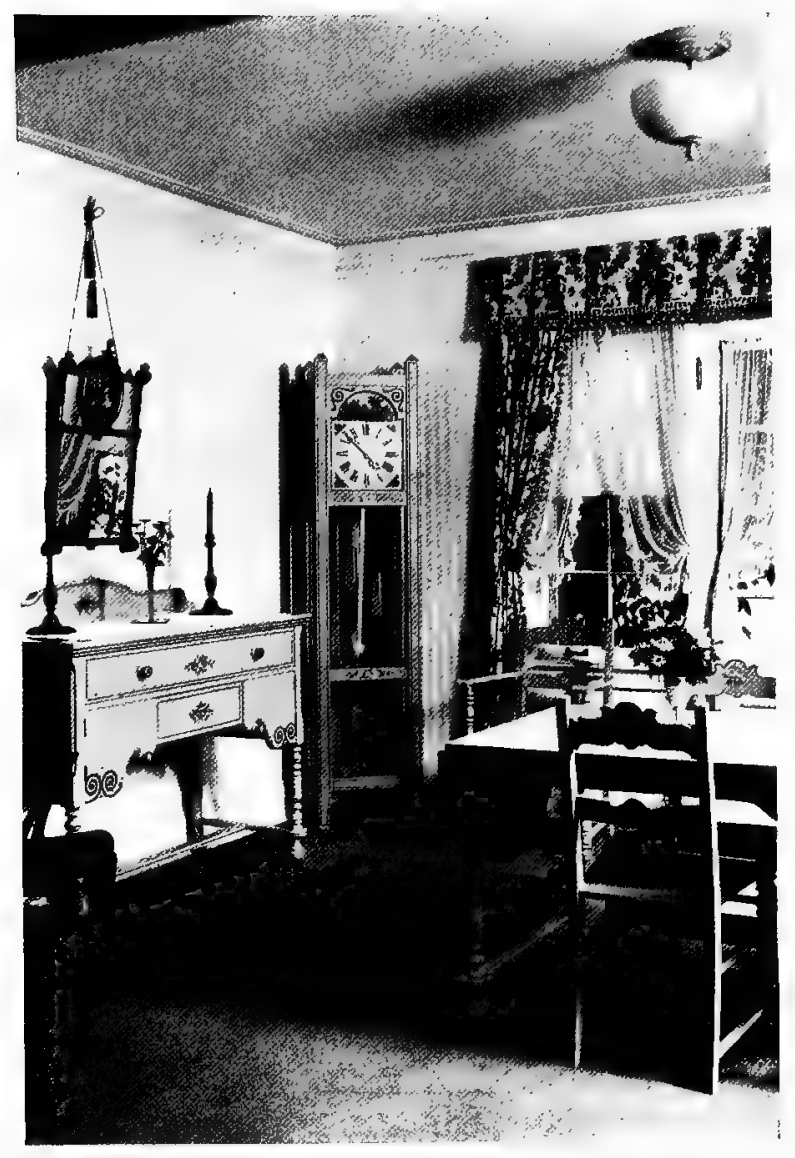

The Clock 



\section{The Building of the Nest}

silence. Rain or shine, day or night, in storm or calm, its drowsy tick-tock talk goes on forever; and when at night the firelight shadows play around its face, its subtle, soothing power is at its best.

And there is a picture painted on the dial. You know it well. I scarce need tell about it. The same that has been painted on clock faces ever since men first became familiar with red-roofed gabled houses, with purling streams, birds, flowers and trees, for background. Once I was well acquainted with another clock that stood upon an old-time kitchen shelf. I don't even know who has it now. I wish I did. I would go a long way to see it. And yet, what would be the use, for is it not before me now? Can one forget such things? The peaceful landscape done in colors gay upon its dial is likely badly faded now. And there was a little church in the background. 



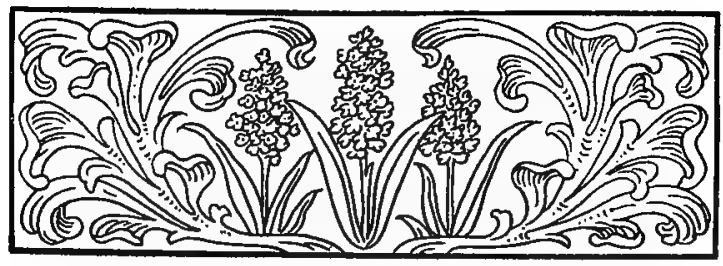

\section{CHAPTER II \\ Behind the Backlog}

A GREAT day that when the storm$A$ doors and windows all come down and we let the sunlight in. This ceremony is commonly celebrated in April. Of course various exploring expeditions always precede the first real lighting of the fire, and the actual starting of the clock. These must wait yet a little while. But the knowledge of the certain joys they are to bring is ours already.

Andy, the watchman, tells us that the snow along the hedge-row out in front had been piled so high that in his winter rounds he walked safely over the top repeatedly. This we could well believe, for unmelted remnants of great drifts were still in evidence in 


\section{The Black Swans}

the early spring. And while I think of it: if you have a Rambler rose to which you are specially attached, and it is growing all over the front of your pergola, decking it in beauty every June, and you do not want it winterkilled and you leave it to some "nut" to take care of in the fall, and he does it up splendidly in corn-stalks, and a cold and cruel winter puts the rabbits hard to it for existence, and the "bunnies" eat all the bark off poor Dorothy Perkins's stems, and you find the rabbit's nest still there in April-but no rabbits-and your rosevine is dead as the prophets, and you are sore and sad, do not kick anybody or anything except yourself for an unconscionable idiot for permitting so silly a bit of fool preparedness. You do not miss your rose until it's dead, and even the least of "blessings brighten as they take their flight."

The winter you must understand has been spent in town in the surly 


\section{Behind the Backlog}

company of unresponsive radiators. You can't get a word or a "rise" of any kind out of any one of them. I have tried it and know. All you can expect is mere heat. True, that is no bad thing to have around when, as happened only last January, you are snowbound for days while deep drifts are being opened up to traffic; but you can study a radiator just as long as you like and $I$ will wager you will receive not one single inspiration from it, will see not one picture of any kind, nor hear the sound of any voice. That is the fundamental difference between dead hot metal and living fire upon the hearth. But if you are only patient you have always this assurance blest - the sun-fires overhead will surely come at the appointed hour and the outer door be opened.

Meantime, mysterious forms of the life everlasting, underneath the snow and ice at Dumbiedykes, are also waiting and watching, just as anxiously as we ourselves around the steam coils, 


\section{The Black Swans}

for the approach of spring. We left them there last fall, these bulbs that were to be our hyacinths, and in their long duress they did not lack for company. Their kin-folk, the tulips and the daffodils, were by their side, the valley lilies, too, and iris; and the slumbering subterranean capillaries of the lilacs and the oaks.

\section{Lines on the Planting of the Hyacinths at Dumbiedykes}

Out of the earth thou camest,

To earth return.

Thine the eternal mystery!

Out of the darkness cometh light and life. Sleep sweetly, therefore, happy hyacinth!

Soon shall the drifting snows Seek out thy resting place And hold thee in their close embrace. And through the dreary midnight hours The glittering stars that glisten brightest When the Frost King rides triumphant Through the northern skies,

Shall guard thy rest.

Fear not.

Within thyself dwells immortality! 


\section{Behind the Backlog}

In God's own time

The sunshine and the showers

And soft caressing southern airs

Shall come and bid thee rise.

And clad in garments green

And bearing in thy sheltering arms

The fragrant fruitage of thy heart

Thou shalt come forth in beauty bright

To greet a world renewed.

And in thy blossoms fair

We find and understand

The truth.

The odor of the hyacinth is the one thing in all this world that never fails to take me back at once to another country home. Father's, however, were always potted or placed in water bottles and hidden away somewhere in the deep recesses of the cellar for their hibernation. Mother's cellar! Its shelving laden always with rich stores of sweets, jams, jellies, and preserves; each Mason jar filled and sealed and labeled under her own personal direction! Yes, often the whole inviting process performed by her own busy 


\section{The Black Swans}

well-skilled hands! Their work was long since finished, and he who brought each spring his hyacinths out of the darkness into the light that they might bloom for all of us is not here now! Red and white, and pink and blue, I see them still upon the window sill. And their perfume is not lost.

The nights are always cool in the midst of so much encircling verdure through the months of May and June, and sometimes as late as July when "dear Zeus" answers the Athenian supplication for rain "down on the plowed fields and the plains," the black swans of the fireplace seem to also hear, and know their services are wanted. The truth is the spring fires burn here with almost unfailing regularity, and Henry has to look well to the wood-pile or we lack proper supplies. A good faithful fellow, Henry! He owns a little place himself not far away, and markets with us such wood as he can spare, and I am 


\section{Behind the Backlog}

not sure that his forestry operations are always carried on in strict accordance with scientific principles. You know that the infernally efficient German Government permits in Germany only the cutting of an arrount of wood each year that measures the computed equivalent of what Nature has that year added by the ordinary process of growth and maturity. I am not going over to investigate Henry too closely either in regard to this matter, and the Kaiser, thank God, has not yet jurisdiction here, even though this is a township bearing the now unhappy name of Bremen. Perhaps if our loyal Lowden remains governor of Illinois long enough he may have this blot on the Cook County map removed. And speaking of the governor and of forestry, that was a fine thing he did many years ago on his estate at Sinnissippi. On the sand hills overlooking the Rock River Valley hundreds of seedling pines were set 


\section{The Black Swans}

where nothing stood before, and hardy conifers are now growing, while he governs, into timber that some day may be sadly needed.

Once upon a time the upper Ohio River valley was famous for its forests. Here and there Indians had opened little clearings where squaw-farming helped forefend the hours of famine. In the wide expansion of the arts of agriculture that followed the great wave of emigration that poured over the Blue Ridge from the Old Dominion after the close of the War of the Revolution, the Virginia pioneers, first in Kentucky and then in southern Ohio, laid the axe ruthlessly to a million monarchs of these ancient forests. The soil into which for uncounted generations they had sent their roots was now wanted for the plow. Huge heaps of logs were rolled together and put to the torch; great oaks, walnuts, hickories and beeches "in one red burial bent." They had no value then 


\section{Behind the Backlog}

because of lack of transportation and a market. There came a time one day, however, in the national life when a bridge of ships across the sea had to be builded quickly lest a world revert to a barbarism worse than that which had once burned captives at the stake in these same Ohio forest clearings; a time when all this slaughtered timber would have helped to win the greatest battle of the ages! However, nothing in nature is ever altogether lost, and so it comes to pass in the fullness of the years that the dust of trees thus wantonly destroyed in days lang syne helps to sustain at last the meadows, fields and gardens now contributing to a Nation's harvest.

Descended as I am in all lines from these log-rolling, rail-splitting Virginians who opened up the virgin forests of the Appalachian slopes, is it any wonder that it has always seemed to me that a home that has not the glowing back-log for its background is no 


\section{The Black Swans}

home at all-just a mere place to stay and vegetate until you can get settled by an open fire, and so get in touch at last with all the Universe?

The woodman who brings not hickory to me is not my friend. I know it is becoming scarce and that it should not be burned at all in these belated and berated conservation days, but I ask for so very little, just enough to get the snap and a certain flame I love to watch on evenings when it's dark and wet and drear out there beyond the window-sills! In fact, your true fire-worshipper's enjoyment of his fire begins with the selection of the proper materials for it. This service he should always render himself, if he wants things as they should be, for there are a million different kinds of fires-one to fit every conceivable human mood; and who knows quite so well as I myself what may be on my mind tonight, and just what type of fire companionship I want? You can no more 


\section{Behind the Backlog}

make a fire for some one else than you can successfully pick a wife or husband for another person. It's chancy enough, some say, to pick one for yourself, or be picked, as the case may be; and the building of the fire, if it is to be considered as a fine artwhich I certainly contend it to be-is not the simple act it seems. I speak of course from the standpoint of those fortunate few who have been blessed by Nature with the gift of reading firelight mysteries.

That oak now flaming so brightly on the fire seems trying to tell me something. When I turned away a while ago it lapsed into absolute indifference, so I give it a good poke and listen to its simple story. What did it say? A lot. Much more no doubt than you would care to hear. I had been reading Parkman and his thrilling tales of how a great new world was found by France and lost again. This oak was from a tree that once had 


\section{The Black Swans}

stood upon the top of that range of hills to be seen there on our western horizon. In the valley beyond flows the little river called Des Plaines. Farther north a low water shed divides its drainage from another stream, once known as the south branch of the Chicago, that emptied into the big lake. The portage was a short one for the aborigines and for the explorers journeying from Mackinac to the Mississippi. My guest from the hills is telling that his arboreal ancestors stood and watched with wonder LaSalle and his intrepid company pass silently below between those brushy banks, his barges freighted deep with fate for France and you and me! His works, his deeds, live after him! And the oak now falling into ashes on the hearth is saying that before it came to us it threw its own seed on the soil from whence it sprang, and other oaks for other fires are growing where it fell. And so we learn again. Each "little 


\section{Behind the Backlog}

life is rounded by a sleep," but nothing worth while ever really dies.

In the glowing embers there are pictures now. The Des Plaines has led us southward. The waters of Fox River are emptying into the Illinois. Starved Rock looms in the distance. The Illini perish. Tonty passes. Some stunted trees are clinging to their ancient sand-stone cliffs. Far to the west and north beyond the fertile prairies where the waving oats and rich green fields of tasseled Indian corn now tell each year the story of a thrifty husbandry, the Sinnissippi Valley lies in all its beauty. The little hamlet, Grand Detour, still dozes by the river's edge. And farther on a colossal figure from a dominating height commands perhaps the fairest landscape in all this teeming west. Black Hawk! A grand conception, that great monument, the handiwork of Lorado Taft! The last great chieftain surveys the once happy home of the vanished 


\section{The Black Swans}

tribes. Poise, dignity, faith, pathos, patience! The red warrior with folded arms and vision keen recalls a sceptre lost and calmly waits the verdict of the centuries. On the very verge of the precipice at his feet a blasted cedar stands, defying the lightnings of the passing years. Tradition has it that the eagles nested once within its scraggy arms from which all life has long since passed. Fit symbol this of broken hopes; and what a story could be told if any one of its skeleton arms were placed upon our fire tonight! But it is sacred now and for all time.

Were the red men as savage as they have been painted? Perhaps. We know that the Iroquois, the most intelligent, the most capable, the most outstanding of all the so-called uncivilized races of which there is record in the world's history, extended their armed sway across the American wilderness as far west as the land of the Dakotas. But their worst has been 


\section{Behind the Backlog}

more than surpassed within the past four years by a fiend incarnate claiming partnership with the christian God!

I stood one day not long ago on Black Hawk's high Rock River crag; and a few hours later traversed the great armed camp at Rockford, where forty thousand brave bronzed boys were in training for the task of helping trail the tiger to his lair beyond the Rhine. I saw the Eighty-sixth Division making ready for immediate service overseas. They call themselves the "Blackhawks." They have officially adopted the Indian word, or words, that signify the old chief's name in his native tongue, as their battle cry. And so the spirit of a so-called savage past has at last come to be invoked in the common struggle in defense of elemental human rights and liberties. 




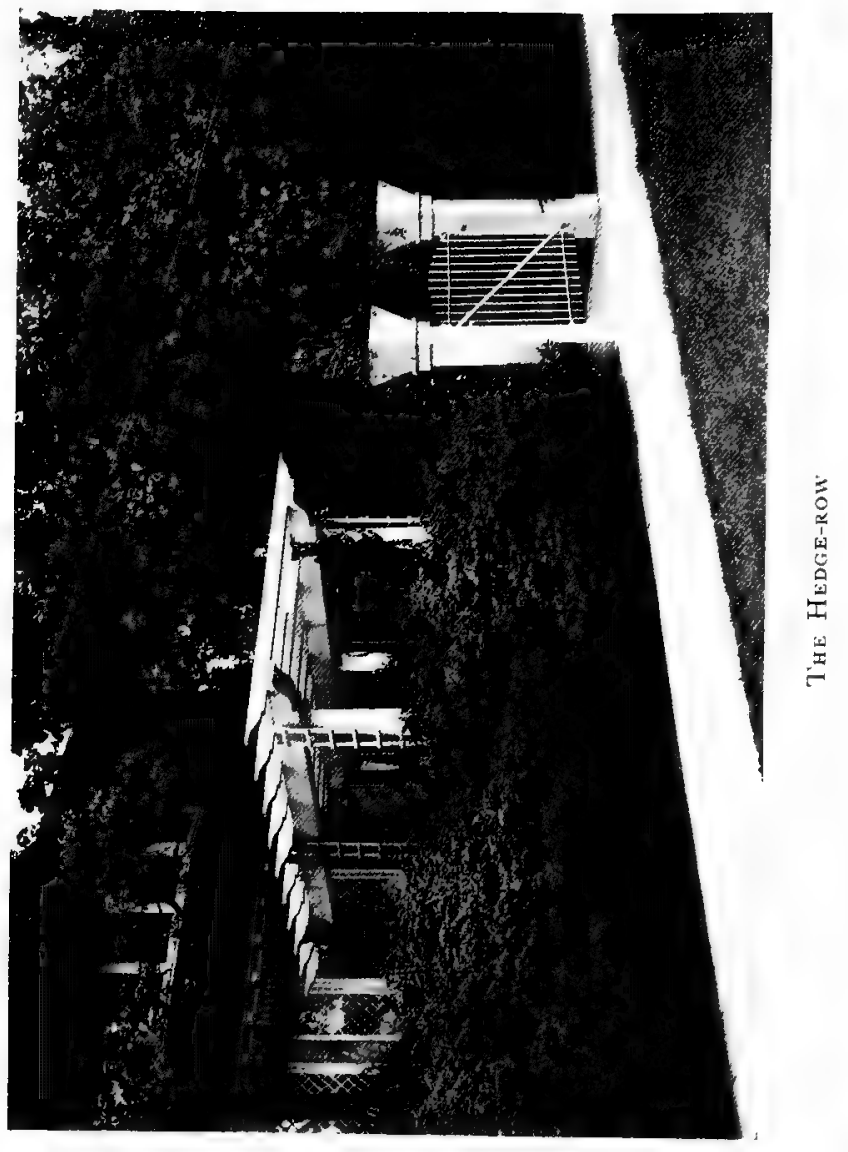




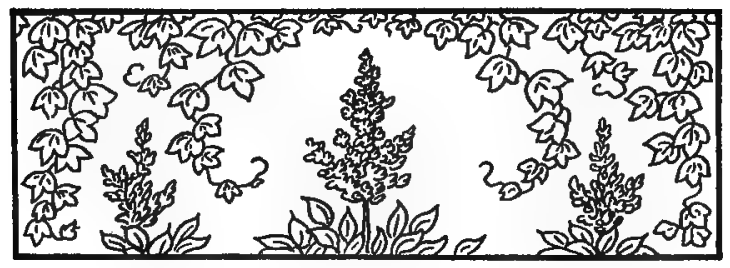

\section{CHAPTER III}

Half-Hours with Mercury and Vulcan

7 HERE is still a chill in the air 1 this day in early June. The Great Lake's breath is yet drawn deeply from the far-off northern reservoirs, and by that same token we shall have a goodly fire again tonight. But meantime the sun is warm, and out there on the lawn, protected from the wind by the shaggy grove that guards us on the east, an arm-chair looks inviting. It's just an out-of-door sitting room anyhow, this little lawn at Dumbiedykes. The hedge-rows all around have grown so tall you can't see out nor in. So here we are, the world all barred away, shut off from all except our own. 


\section{The Black Swans}

The cat-birds like it too, and we like them. They are so trim, so neat, so "tailor-made," as Billy says; and friendly always. They reproduce themselves in two short weeks, and in ten days more the mother lights upon a twig above the nest where they were born and fed and clucking to the tiny chicks with fluttering wings she tells her wee ones of a great adventure now at hand; and one by one they struggle out and take their places in the big new world. And who shall say that place of theirs is unimportant? It may seem so to us, but who are we? That is their question. And from their standpoint what is it we do to justify our own existence? One thing at least it seems the cat-bird, in common with the robin, gives us credit for. Wherever we build our own nests, the robber birds - say the blue-jays or the crowsdo not come close. Our eaves and porches look good therefore to Cock Robin, and a cat-bird dearly loves 


\section{Half-Hours with Mercury and Vulcan}

the cover of a bush that's near your door.

How grateful is that sun! How blue the sky! How green today the ivies and the Persian lilacs that near obscure the soft-gray stuccoed walls. The outer hedge-rows throw their emerald belt about it all. Not even sound obtrudes upon seclusion all but absolute, save the rustling of oak leaves over-head. And so I doze and dream. My book today has chanced to be The Odyssey. In obedience to Jove's command the winged Mercury has just alighted on Calypso's fabled isle. I love Leigh Hunt's translation, and wish you would read it with me.

"And now arriving at the isle, he springs Oblique, and landing with subsided wings,

Walks to the cavern 'mid the tall green rocks, Where dwelt the goddess with the lovely locks. He paused; and there came on him, as he stood,

A smell of cedar and of citron wood, That threw a perfume all about the isle; And she within sat spinning all the while, 


\section{The Black Swans}

And sang a low sweet song that made him hark and smile.

A sylvan nook it was, grown round with trees, Poplars, and elms, and odorous cypresses, In which all birds of ample wing, the owl And hawk, had nests, and broad-tongued waterfowl.

The cave in front was spread with a green vine,

Whose dark round bunches almost burst with wine;

And from four springs, running a sprightly race,

Four fountains clear and crisp refreshed the place;

While all about a meadowy ground was seen, Of violets mingling with the parsley green."

And then I wake. Around about me the enchanted island washed by blue Aegean waves! No, it cannot be, for it is mint I smell, not cedar nor yet citron wood. And those fountains, are they really racing through the violets and asphodel? It is not so. No Mercury appears; only Henry in blue overalls and he has just laid the nozzle of the garden hose down there among the 


\section{Half-Hours with Mercury and Vulcan}

pink geraniums, and is replenishing the bird-bath yonder underneath our best white oak. And he is not using a graceful Grecian urn; just a common old watering-pot with a broken spout! And the goddess herself is not inside. That is no whirring spinning wheel you seem to hear. It is Kate and the vacuum cleaner hard at work. That's all. In fact Calypso really spread her wings early in the day and flew away to town on perfectly good shockabsorbers and sound cord tires to get a golf skirt altered. The parsley though, of which we read, is growing there by Mary's kitchen door. Praise be to the gods for that much anyhow! We had our fire that night all right, and needed it. In the first place Calypso came home not in the best of humor. Even goddesses, you know, are privileged to show temper at the very throne of high Olympus itself! Field's were so busy and so "fussed up" with inexperienced war help that she had 


\section{The Black Swans}

been compelled to wait an hour or two before she could even get a chance to try on the blessed skirt, and even then it didn't fit! And she did not propose to wear the blamed thing anyway. It was a fright! So there! And having once altered it, the firm refused of course to put it back in stock, and what's to be done? She has a match on tomorrow with Cora or GertrudeI don't remember which-and nothing to wear! Can you beat it? I ventured to say that goddesses in the old days were not specially particular, from all pictures, statues and other records handed down, as to whether they wore a lot of clothes when on the Olympian links or not, but this did not help much.

In the second place, had I ordered that coal yet for the hot-water heater? Naturally I had not. Had I not been comfortable out there in the sun-rays all afternoon with Homer and the bumble bees and big brown butterflies 


\section{Half-Hours with Mercury and Vulcan}

attracted by the "perfume all about the isle"? What did such a thing as coal mean to any mere mar under such circumstances? Not a bit more than it did to shrewd, hardworking McInerney that Sunday when Father Dorney made his famous appeal for contributions to buy fuel for the church. You doubtless all know the answer. The good father had observed that Pat had not dropped any coin into the plate when it was passed, and after the service was over took him to task about it. Whereupon the thrifty parishioner rejoined: "Well, Father, ye can't fool me with all this beggin' fer money to buy coal. Ye know blanked well that this church is hated by sthame!" And had'we not good oak and hickory?

But under the mellowing influences of the glow that soon was casting rosy beams of light and gladness all around, the golf skirt that had failed, and the coal that was not ordered, and the 


\section{The Black Swans}

cold rain that now beat upon the window panes outside, were soon forgotten. And the clock ticked on as if in mockery not only of the big, but of all the little, griefs and worries of a foolish world.

And presently, looking at the andirons and the fire, I seemed to see a portrait of a dear old-fashioned village blacksmith, beloved by all who knew him, whose shop was once upon a time to me a place of a thousand mysteries, as well as the unpretentious industrial center of an appreciative farming community. He stands there as in days of yore, one hand resting upon his hip, the other working the bellows, a cheery smile upon his honest face; big-chested, big-hearted, gentle as any child. How we all loved to watch him at his work. $\mathrm{He}$ usually wore a red flannel shirt, with sleeves rolled up, and the inevitable leather apron to protect his clothing from the sparks. Now he draws the white-hot rod or bar of iron 


\section{Half-Hours with Mercury and Vulcan}

from out the flaming forge; fast and hard and true the hammer falls, and the ringing of that anvil beneath his heavy blows is still as music to my ears. The boy who knows not such a picture has missed something.

Vulcan himself could have meant no more to the ancients than did this wonder-worker of the old-time blacksmith shop to the simple-hearted country folk he served so long, so honestly, so faithfully. It wasn't much of a place to look at-this busy little shop of which I speak-just a onestory frame affair with great wide doors, dirt floor; the rafters, walls and corners stored with the crude shapes of iron from which the dear old smithy wrought metallic marvels! It would cut but a sorry figure, to be sure, alongside a great modern forging plant such as that our good friend Ingalls operates now by day and night. And I have since seen big batteries of Bessemer blast and open-hearth furnaces dis- 


\section{The Black Swans}

charging their deluges of liquid ore under roofs that seemed acres in extent, with ingots, blooms and billets, rails and beams traveling around great mills where men seemed to have little to do with anything save to work the levers or press electric buttons. And yet there was that about the little old shop that fascinated boyish fancies even more than all the prodigies of Schwab or Carnegie.

There was a wagon-maker's shop next door, and when the wood was ready for the irons or steel the good smith took his turn. There may be wagons just as good-or, for all I know, infinitely better ones-turned out by modern labor-saving works, but when those which $I$ recall received their coats of vivid green and flaming vermillion paint they were certainly the pride of all the village streets and country roads over which they rolled. And they stood a world of wear and tear. 


\section{Half-Hours with Mercury and Vulcan}

All sorts of simple farming implements and tools came for repairs, and plowshares must be sharpened. And sometimes a dozen horses waited to be shod. The shoeing of a horse's foot interests me deeply even yet. Only last August at the H-F Bar I often visited the busy little shop where Smoke and Blaze and Splash and Colonel and all that bronco generation came-needless to say very decidedly against their own strong. wills-to get the little plates they needed in their summer scrambling on the Big Horn trails. But I did not ask the privilege of assisting at the ceremony there, as I always did at "Uncle Harl's." My share in his place was switching the flies off three legs of a horse while the fourth was in the farrier's apron having a hoof pared properly for the setting of the new and still hot shoe. This fly-chaser was a defunct horse's tail tacked onto a handle. To my mind it was a genuine treasure, 
and those old farm teams were so lovable. They would stand and fairly go to sleep while the old horse-tail fly-brush was being plied and the shoer's work performed. On the ranch, on the contrary, it was in some cases a free fight between man and beast, in which one used a bar of iron on the ribs or head of his adversary, and the other his heels. Even the expedient of tightly roping one foreleg did not suffice in one case I recall. The farrier was temporarily foiled by the little mountain devil deliberately lying flat and kicking on the floor. This particular shoer had a broken leg as a memento of some such former session with a cantankerous subject. But of these broncos more anon. I should not imagine that the managers of accident insurance companies would class shoers of cow ponies as preferred risks in their business.

I know that our fire set could have been made beautifully by hand by 


\section{Half-Hours with Mercury and Vulcan}

"Uncle Harl," and it would have been wonderful to watch him bend and fashion each particular piece as his own fertile fancy might have dictated. How I would love to hear that voice again; it was so rich and deep, and there was no note of anger in all its register. I doubt if a kindlier bigger heart ever beat in mortal breast. His type has passed. Horseshoers we have with us yet, but the all-around constructive, clever, clear-brained, keeneyed individual manipulators of hot iron and steel at cross-roads country towns are, I fancy, in these days rarely to be met.

And now the clock calls "Time!" Bed-time! And it is right, as usual.

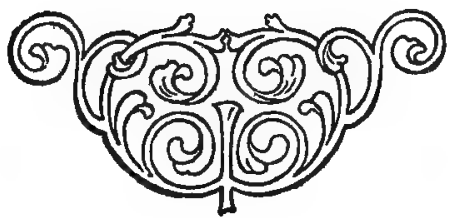





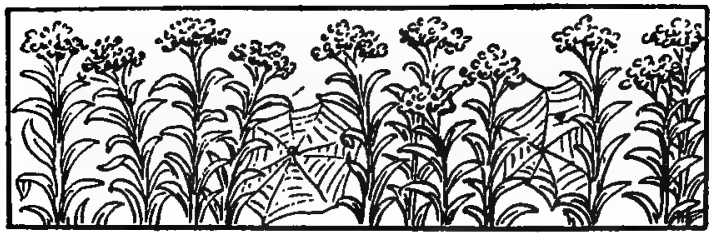

\section{CHAPTER IV \\ Low Tides}

W ${ }^{E}$ have run now into the early summer "doldrums." The last half of July is apparently a period of rest and recuperation after the intense and continuous activities of the weeks immediately preceding. The seeds have sprouted and brought forth. The shrubbery has borne its blossoms. The birds have mostly reared their young and many have already left for parts unknown. The bluegrass begins its mid-summer sleep. The main body of the insect army that makes August ring with entomological melodies has not yet arrived. The mercury flirts with eighty-five degrees in the shade on the porch which is well protected 


\section{The Black Swans}

from the sun by trees and awnings. A very busy birdlet still imagines that the spring is here and carries twigs, and twitters all day long as if it were still mid-June. This particular wren has been known to be at work constructing two or three different nests at the same time. Billy declares therefore that he must be either a Mormon or a bachelor. At intervals a robin repeats his brave spring song, but somehow he has lost his "pep." At sunset the plaintive notes of meadow larks are still sometimes heard, and purple martens "flit and run" through their accustomed evening flights.

The small grains and the hay crop have been harvested. Red clover and white are yielding their honey stores and the bees are swarming. Evidently the parent hives are hot and overcrowded. Only yesterday a colony from somewhere found and took possession of the hollow oak, where once the flickers lived; the same that for 


\section{Low Tides}

one winter housed the ill-fated flying squirrels of happy memory. Sweet clover and tall weeds line the highways. Running out from the city this afternoon we passed through long walls of green reminding us of English laneschiefly because it was all so vastly different. The road did not wind in and out with long graceful curves, and the greenery alongside was neither hawthorn-hedge nor ivy; just weeds, the rank sort that our hot summers force in such abundance. Even the lightnings, winds and rains that a little while ago were playing frequent havoc with our wires have abated their fury in obedience to what seems to be some natural law that ever halts the great spring drive at this season of the year. The fire upon the hearth no longer burns. The old clock only changeth not. Time neither waits nor rests.

The year is in its prime, its middle age. Its restless youth is past. During those turbulent earlier months many a 


\section{The Black Swans}

prospect fair was blasted. Some of our finest plants were hopelessly broken by the driving storms of May. Limbs were wrenched from the maples, and torrential rains drowned various birds unable to save themselves from the fury of the elements. Those trying days though now are passed, and, supposedly, the fittest have survived and inherited the earth. I wonder is this always so? We make a lot of fuss of this business of trying at any cost to keep up with the procession in the struggle for place, precedence or a mere existence! As if life were a matter of years only. May not that boy who died so gloriously today in the fateful valley of the Marne have lived to far more purpose than the seedy specimen of humanity that begged this morning at the cottage door? And yet another query presses. Is that straggling stalk of corn, trying in vain to make something out of itself in that hard clay soil back there along the 


\section{Low Tides}

roadside, to be blamed, because it is not tall and green and fruitful as its neighbor in the well-tilled field the other side the fence? The grains from which they sprang were equally sound last spring and assuredly held within themselves like possibilities. All we know is that one found congenial conditions, the other not. Had that big oak the thunderbolt destroyed a better right to live than its neighbor that endures?

I have spoken of the odor of the hyacinth as invariably recalling childhood days. The whirring of the electric fan, which we on occasions set in motion to freshen up the air inside at this season of the year, with equally unfailing certainty carries me instantly to a summer spent in Washington,

D. C. Once upon a time a message came over the wire in the month of August from the then summer capital at Beverley Farms, Massachusetts. It was signed by William Howard Taft 


\section{The Black Swans}

and requested me to serve as a member of a body which he had been authorized to create under an Act of Congress. Not having sought such an appointment, and being altogether satisfied at the time with life as it was at Dumbiedykes, I hesitated about accepting the service. It happened to be work in which I had been for many years very deeply interested. Moreover, my game of golf was just then of a brand calculated to drive almost any self-respecting person from the links. Furthermore a certain United States senator with whom I consulted concerning the matter intimated that if I did not accept the appointment the President might make a worse one. And so a little later I packed my grip and began my indeterminate sentence.

Now, I like the capital city. Any tree-lover must. And Rock Creek Park is in a class all by itself, but that sea of superheated asphalt, that humid atmosphere, and those awful nights

$$
\text { [ } 50 \text { ] }
$$




\section{Low Tides}

inside New Willard walls! Fortunately

I was not compelled by my official duties to remain there but one summer. That, however, was quite enough to last me a lifetime. And to this day, no matter where it may be heard, the humming of an electric fan carries me forthwith to the hotel rooms in which I lived the best part of four years while trying to do my bit for Uncle Sam. Up around The Highlands and at the summit of the Park, or even on the Speedway down along the Potomac, there was some chance of finding the necessary oxygen, but one could not ride all night, and so it came to pass that the Willard and its fans and the blessed bath tub are associated now and forevermore in my mind with hot weather.

There was another and a brighter side, however, to these Washington experiences. Hard and grinding as was the work; impossible as it must always be to give general satisfaction in the 
handling of vital questions affecting the American tariff, our offices, looking out from an upper floor of the southern facade of the Treasury, directly upon the Sherman monumental group, commanded a superb view of the White Lot, the great shaft that commemorates the memory of the Father of his Country, and the valley of the Potomac as far down as the Long Bridge leading into Alexandria. Beyond that the Virginia hills, which I never contemplated without visions of Bull Run, Fredericksburg, Antietam and Appomattox. Even this would soon have palled but for the unfailing encouragement, support, courtesy and always kindly consideration of the President in connection with the task he had set.

After the lapse of all these years it cannot now be out of place to say that no man ever approached the task of revising the tariff laws of the United States with higher courage or greater 


\section{Low Tides}

honesty of purpose than did President Taft, and while his plan was successfully opposed by political adversaries and distrustful manufacturers within the ranks of his own party during the years we were engaged upon it, he has lived to see everything for which he so valiantly contended at that time approved and enacted into organic law by Woodrow Wilson and the very men in Congress who put to death the original Tariff Board of which I had the honor to be a member. Perhaps then, after all, the weeks and months away from my own fireside and business affairs, spent first in wrestling with Count Bernstorff and M. Jusserand over German-American and Franco-American trade relations, and secondly in grappling with the intricacies of "Schedule $K$ " were not entirely wasted. Somebody has always to do some plowing before some one else may reap. Some one has to ride ahead and help blaze the legisla- 
tive trails that may lead ultimately to national progress.

The subject of our commercial relations with the world at large is one that has always appealed to my imagination. My personal activities have dealt mainly with questions relating to the production and marketing of the products of the farm rather than those of the factory, but there is such an intimate and undivorcible relationship between the two, and such a vast field for the exchange of vital international concessions in arranging our affairs with other nations, that not even the delights of Dumbiedykes shall ever bring my interest in that subject entirely to an end. And as the close of the great war comes in sight, who shall deny the fact that the business readjustments between the nations, rendered imperative by the financial and industrial earthquake through which we are passing, shall be a matter demanding the thoughtful 
and intelligent consideration of every patriotic American.

A cool breeze is springing up now. The electric fan that started me, in an unguarded moment, into talking "shop" is no longer needed. Let us therefore shut it off and bury for the present, in its silence, our memories of those tropic nights when even the cold water ran hot in New Willard tubs.

Low tides come to us all at times I fancy. We cannot always be riding happily upon the flood that leads to joyous fortune. That larkspur blooming there so gaily, with its tall blue flower stalks rising far above its floral neighbors, is not always decked out thus. It has been comparatively unnoticed in the garden until now. It will add its beauty to the scene for yet a little while, and then is gone. And thus with all created things. How cruelly short the hour supreme when life flows at its highest tide! And yet those 


\section{The Black Swans}

long and tedious days or weeks or years of unconscious preparation that finally lead us up to these summits of existence are apparently an essential part of the Eternal plan. The Century plant in bloom at last no doubt finds in fruition long delayed the fond consummation of all its most cherished hopes and dreams. And that happy dragon fly that is born and lives its shining hour and dies! It no doubt also calls the world just wonderful! At least let's hope he does.

There come times I suppose to all of us when we must seek some Walden Pond and woods or just "blow up." Rest is imperative. Dig as we may, seek as we like "the bubble reputation" no matter where or how, pursue ambition's call; receive, if you are fortunate, that worldly crown men call success, yet soon or late the jeweled blade that led you on must be thrown back into the waters of the lake whence it had been thrust by hands unseen, 


\section{Low Tides}

and shadowy shapes appear to bear you to your Isle of Avalon. And so we cling each to his own particular Excalibar until the last.

Speaking for myself, in the course of various quests for mental relaxation, I have made some few discoveries. I know that one of the greatest things in the world for me is the open fire at Dumbiedykes. Another is that ordinary cares are easily forgotten in any unfrequented nook well forward on the deck of an ocean liner speeding noiselessly through tranquil summer seas. A third situation in which right perspectives have sometimes been attained is a mountain height with the earth and all the fullness thereof apparently at one's feet. And if I were to add a fourth never-failing source of inspiration - and I am not sure but it might be first-it would be music, preferably Grand Opera, provided only it be not of the heavy brand they make in Germany. 


\section{The Black Swans}

During these dog days I cannot have my fire. The sea-thanks to the shameless effort to enforce the Hohenzollern brand of civilization upon an unwilling world-is for the present the last place towards which one would turn for relaxation undisturbed, but I still look back with memories filled with pure delight to restful hours aboard the old Majestic of the White Star fleet on my maiden voyage oversea. And other near approaches to Nirvana were enjoyed again when, on another holiday, the Azores hove in sight as the fast but ill-fated Columbia glided on her peaceful way to sunny Italy. She is now, I believe, somewhere on the ocean floor in Oriental waters. Yes, and the Lusitania too, now rolling in her deepsea grave, once on a time raced eastward by "the Banks" through shifting fog-drifts, alternating with glorious sun-bursts, in a series of matchless moving "marines" that shall hang in the galleries of recollection until the 
end of time. We were bound upon that voyage for the Scottish Borderland, for a certain stately manor-house where giant beech-trees rear their venerable boughs, not far from where "Sweet Teviot" pours out its silver tide into the Tweed. But that is another story.

The fire-place is for the time being impossible; the Seven Seas are for the present, as far as ordinary travel is concerned, verboten, and the winged violinists of the grass and hedge and trees are only just beginning to arrive. But there is left the mountains, and it has been years since we have been among them. Let us now therefore seek their solitudes. And while you are getting ready, may we gossip for a time of mutual friends?

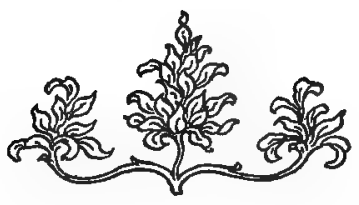






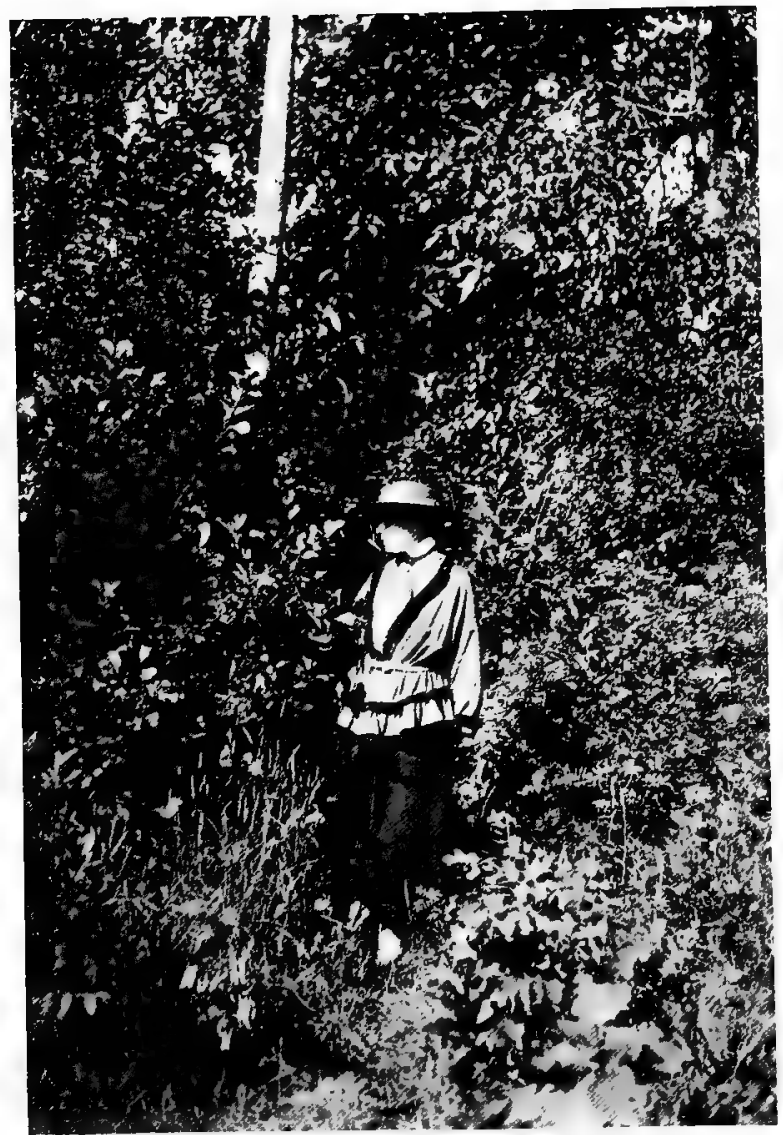

"BILly" 


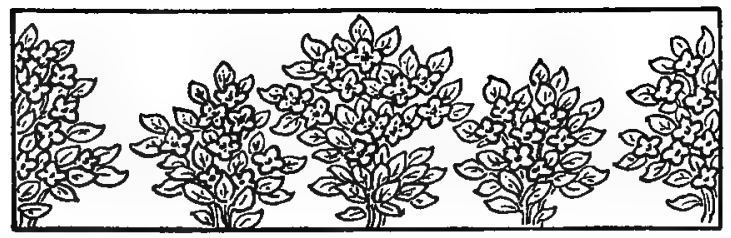

\section{CHAPTER V \\ The Case of Kate}

N the evening of July twenty-six, it must have been about nine o'clock, I sat reading near an open window. The day had been hot and sultry, and the moon which had passed its "full" had not yet shown. Lyra was gleaming brightly overhead with Vega flashing steadily its blue-white fires. Arcturus glittered in the west. Suddenly from somewhere in the shadows of the lawn a sound, faint and inarticulate, it seemed, yet nevertheless distinct to one whose ears are keenly attuned to the voices of the out-of-doors. I listened intently for a time for a possible repetition, but the almost perfect silence of the summer

[6I ] 
night was quite unbroken. While I had not been positive, yet I would have sworn that I had heard in almost whispered accents the one word "Kate!"

The sound that I had thus interpreted had rather startled me, because it was a signal that I clearly understood; one that had to me a very definite meaning if it had really been given. In fact, it was to mark a very important episode in the season's happenings. The only question was had the word actually been pronounced or had my imagination only deceived me. This I was inclined to believe had been the case, for the tones employed had been very weak and seemed to come from far away. I reported the incident to Billy, and asked her if she had heard it, but she had not, so I said:

"Well, at this same hour tomorrow night we will know for certain, for if I heard that which I am not at all 


\section{The Case of Kate}

sure I did hear tonight it will be repeated. Of that we may be absolutely sure. If it is not, then we shall know that I was only dreaming."

I knew from past experience that there would be no further evidence that evening of the presence of the only one in the world who each year thus heralds his coming, and so I was not at all surprised that the only further sound that broke the silence of the night in question was a sudden piercing scream, followed by a series of muffled tremulous notes that came from the black cover of the trees on neighbor Alexander's place. There could be no mistaking that. A predatory undesirable citizen of the forest of whose nocturnal habits and wanderings we do not approve-brer owlhad possibly made a kill. Presently this was heard again in the farther distance. Then all was still.

At almost precisely the same hour on the following night Billy called:

[63] 
"Come quick! I heard it! I am sure I did!"

I knew that if matters were moving, as I now fully suspected, some minutes were likely to elapse before any further progress in the action of the play was to be anticipated, so I did not hurry, but making the open window at the psychological moment I caught in subdued yet unmistakable staccato:

"Kate! Kate-kate! Kate!" Then silence.

The voice was the same that I had thought I heard twenty-four hours previously, only now it was stronger. Its exact location could not be determined, and I wasted no time trying to make out the particular tree or clump of bushes whence it had emanated, for long familiarity had made me too wise to expect any further developments even on the second appearance of this strange visitor from the unknown. I could now figure with exactness. 


\section{The Case of Kate}

"Tomorrow night, if there be no disturbance of the elements, at this same time he will call again. Not only that, but a little something will be added to his utterance; and what is of much greater importance, he will not be alone. At least one of his pals or kinsmen will be with him."

And lo, on the third night, promptly on the hour:

"Kate! Kate-kate! Kate-kate! Kate-kate!" and then the other word, which was as sure to follow as night is certain to succeed the day, "Ka-teedid," with the emphasis upon the last syllable. That was all until from another quarter came a low "Kate! Kate-kate! Kate-kate!" from one that had just been aroused from his long sleep.

So they were here, sure enough, the advance guard of our old friends. They were nearly a fortnight ahead of their accustomed schedule, and on the next night two or three more hatched out 


\section{The Black Swans}

and gave expression, twice repeated, to the only word they know when first born; while the pioneer, now three days old, having finished the cicadian curriculum proceeds to launch the strange dispute that is only ended by the final collapse of all who participate so strenuously in it.

"Kate! Kate-kate! Kate-did! Katee-did! Ka-tee-did! Kate-did!"

The issue is now to be squarely joined, for from the next tree or hedge comes the quick retort:

"Kate! Kate-kate! Kate-did! Katee-did! Ka-tee-didn't! Ka-teedidn"t!"

They are off now in a bunch, and from that night until frost stiffens their green frames, so that they can no longer take a part in the proceedings, the dispute goes on with unfailing regularity and it is always held under time-honored United States Senate rules. The application of cloture in this case has yet to come. They 


\section{The Case of Kate}

recognize no right on the part of any member of their body to try to limit debate by moving the "previous question." Neither will they consent to the fixing in advance upon any hour or time for taking a vote on the guilt or innocence of the accused. They just keep it up as long as they have strength enough left in their bodies to express their sentiments-which are obviously badly mixed-and it is not until we come to the death-bed evidence of the last of the tribe that we apparently get a decision; a verdict which so far as I have been able to make out is invariably against the defendant.

I have only the highest respect for those scientists who can devote a lifetime to studying through a microscope the eye of a butterfly or something like that, and then write thick volumes setting forth, with a devotion worthy of any cause, and illustrated by innumerable color plates and careful 


\section{The Black Swans}

drawings, the whole wonderful scheme disclosed. And all the while they might have been very much more unprofitably employed. They might, for instance, have been selling to a gullible public mining stocks, or oil-lands on the slopes of Popocatepetl, or coffee plantations where the cocoanuts and paroquets and monkeys grow. They tell us many marvelous tales about the bee and ant and spider that many generations of men have accepted without question. There is no one to dispute their statements set forth as they are with such great wealth of detail. Fabres do not live in every generation. It is not therefore for any mere layman or woman to question seriously, even for a moment, researches made with a patience that can only evoke our profoundest admiration. So when they tell us that the male does all the talking in bugdom, I suppose there is nothing to do but to accept the statement. True, if we mere humans 


\section{The Case of Kate}

stop to reason by analogy we might be quite inclined to question an assertion so entirely at variance with our own experience. In our hearts, however, we can but marvel that an Allwise Providence should thus discriminate as between mankind and our obscure brothers of the bush. I am perfectly willing to let these teachings therefore go unchallenged, because I must admit I have no lens powerful enough, and have as yet found no day or night long enough, to enable me to file any demurrer based on actual personal investigations in this case of Kate. But for this admitted fact, I should be inclined to reason thus:

It is a fair assumption that in such a long and acrimonious contention as that concerning which we write, the female is morally certain to have the last word, the closing word, the word which finally prevails and is not answered. The one fact we have upon which this verdict in Kate's case is 
based is just this: The last one leaves off just as the first one began, or rather I should say, reverses the proceeding, gradually dropping the "didn't," thus abandoning the denial and lapsing at last into enforced acquiescence. Now it is a commonly accepted statement that females are much harsher in their judgments of one another than males. Where one of their own sex has been accused of any misconduct they show little mercy. They are even sometimes accused of being "catty," one with the other. There are of course exceptions to this as well as to all other rules, but in the main they are not naturally inclined to be specially charitable to one another in cases involving alleged violations of the conventionalities. Especially is this apt to be the case if the one sitting in judgment happens to be old enough to concede without debate the probable error of the ways of those who have perhaps not yet altogether settled down. So getting 


\section{The Case of Kate}

back to the case of Kate, it seems to me foreordained that she is, under these circumstances, almost certain to be found guilty. And this is what happens.

Weakened by exposure to cold wet weather in the fall they one by one give up the ghost and creep silently to rest. The one with the final "say" having now contracted wing-itis is, at the end, only able to reiterate, and feebly at that, "Ka-tee-did." All opposition ceases. And after a pause it all ends just as it had begun on July twenty-six with a feeble "Kate-kate! Kate-did!" and then, last word of all, just "Kate!"

I hold no brief for Kate, but merely in behalf of millions of lovers of truth, justice and fair play, who know little of sex and songs and family jars in the insect world, and who can with the lights at their command pursue no other line of reasoning, I respectfully suggest to all naturalists of high and 
low degree the possibility of error as to the male doing all the talking in this particular instance.

We don't know what the charge has been. Probably we never shall know. We only know that the "dids" win out invariably at the finish. That Kate, poor Kate, whoever she is, whether one of their own number or some Catherine of higher degree whose fate has proved of perennial interest to the tenants of the hedges; that Kate, poor Kate, whatever it is she did or didn't do, as matters stand, is most assuredly condemned. Kate did it. At least so the record uncorrected runs.

And now if you have on your riding "togs" together we will take to Big Horn trails.

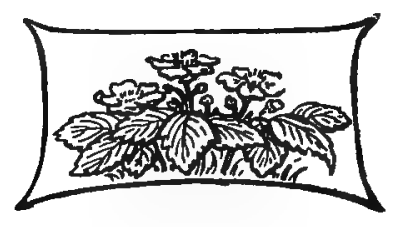





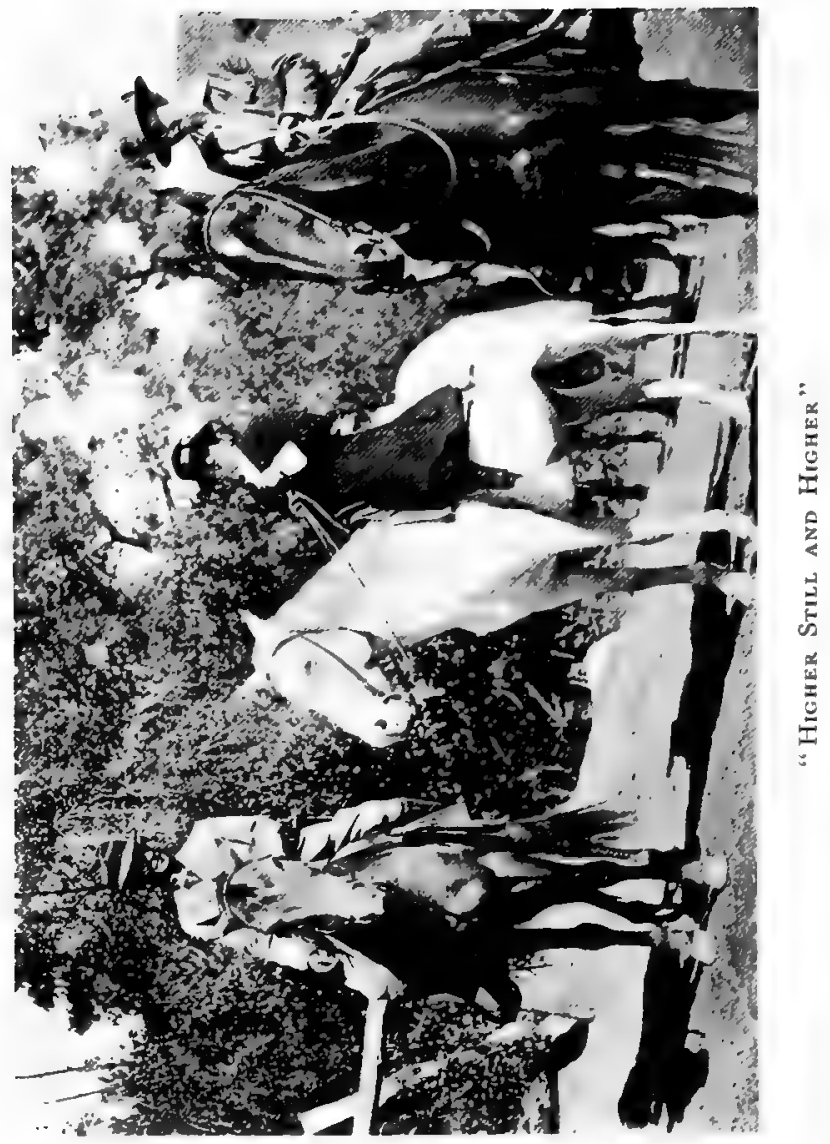




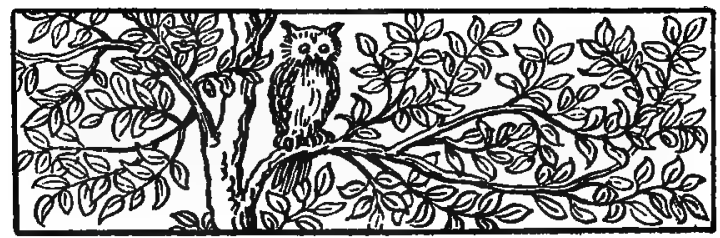

\section{CHAPTER VI \\ Smoke of the H-F Bar}

ES, "Smoke." That was his name.
He was only a cow-pony on a western ranch, but he was wise, and, unlike some of his kind, quite an agreeable companion. In fact, I can say in truth we spent many quite happy hours together. He was not specially communicative, and yet many a time when I had dismounted and thrown myself upon the ground to rest and get in touch with all that is revealed from some of the higher Big Horn slopes, he would pause now and then in his grazing by my side to poke his muzzle along the sleeve of my riding coat and look at me with big brown eyes. Just what it was he said to me 


\section{The Black Swans}

I may not tell, for it was strictly entre nous.

You had only to throw your reins to the ground and Smoke was hitched for the day, and in the course of six weeks of intimate companionship I discovered that this was specially true if I happened-as was often the caseto stretch myself at his feet to bask with the "rock-chucks" in the warm high mountain sun, and enjoy with them and Smoke the eternal snows, the towering rocks, the sapphire sky, the irrigated valleys far below with emerald green alfalfa fields, or ponder the inscrutable mysteries of the distant Bad Lands.

One who has known the joys that wait upon a frosty morning's ride along smooth Appalachian bridle paths with a gaited southern mount will balk at first when he sees the H-F Bar corral and its motley aggregation being roped and cinched. All shapes and sizes and colors from the speckled 
Remingtonians to the comparatively shapely ones that show a cross or two of horse! But when you know them better and grow familiar with the sort of service they perform for inexperienced hands your hat will come off to these same ragged rugged products of an iron environment, and you will know that Nature rarely makes mistakes.

On these self-styled "dude" ranches of Wyoming a pony goes with each cot and the "grub"-all included in the price where city folks now sometimes go to make first-hand acquaintance with the west. At the H-F Bar the pony is yours to have and to hold-if you can-so long as your vacation lasts. You may not like the first one you draw, but if it so transpires that you do not, you have only to file application with Harry, the senior wrangler, for a change of venue, and perhaps you will get a worse one. Perhaps, however, this bronzed and keeneyed veteran who knows the bronco 


\section{The Black Swans}

as an open book will let you in right. Harry and Ray, his tall and typical moving-picture mate, are all right. They know their business just as the ponies do, and that means that they all "savey" well their own particular jobs and multifarious responsibilities. You cannot say as much for most of the eastern tenderfeet who swarm around the saddles every morning. Most of them do not know just what they do want in the equine line. Men with "shot" nerves, men whose idea is that heaven lies near where a speckled beauty swims below the tip of a jointed rod, women who are looking for lost weight and women who are willing to lose it; children, too, the boy who buys a hunting knife and "chaps" before he has been on the ranch an hour, so he can look a cowboy bold, and the "kids" who are to have their first lesson here perhaps on "Sausage" or some other fat old veteran of the band. 


\section{Smoke of the H-F Bar}

Splash got his name, as had Smoke, White Man and Blaze from peculiar color markings. Splash was Billy's, and the only "racker" on the ranch. He was black, with a few white splotches, and here and there the black and white so intermingled as to produce a peculiar grizzled mixture. He was nimble on his feet, quick as a cat and the easiest-gaited pony on the ranch. In common with all the rest, however, he invariably took the first touch of your toe in the stirrup as the signal to be off. You are supposed to swing yourself up into the saddle as they fly away. Billy can tell you best about this. She made a noble effort one fine morning to get aboard in time, but Splash was just a little bit too quick. But she will have to tell of that herself.

Blaze was a decidedly good mount. There is real horse in him. That is to say, he was not of the pure native blood. In conformation, size and gen- 


\section{The Black Swans}

eral character he stood out somewhat from the common herd. And he, like Splash, was not assigned promiscuously. He was one of those face-cards in the pack, apparently held up his sleeve by Harry, to be dealt only to some one who had first demonstrated a capacity for really enjoying his good points. This chanced to be Lucile. Now Lucile had not been just fortunate in the original draw. Her first one was too slow, and Prince had proved a surly, heady brute, always looking for a chance to get the bit between his teeth and go. White Man, a little the worse for wear perhaps, but still with much in his favor, was the next candidate, but one day he had the misfortune to fall flat, so still another was requisitioned. The lady had through all this clearly established her claim to better treatment, and thus it came to pass that Blaze was duly awarded her, and so far as I know ridden happily ever after. 


\section{Smoke of the H-F Bar}

Wise, did I say? Solomon in all his glory or the Lord Chief Justice himself in wig and gown, may be set down as "pikers" in comparison with these hundred ponies of the H-F Bar. What they do not know about life on their own stony hills and treacherous trails would not be worth printing. And they have come to know the "dude" and his ways quite as well, and how they do delight to "work" him! When it comes to wrestling with the hardships and the dangers of the wild, in the hard school of which they were born and bred, they act on instinct infallible. There are certain things they fear. Their ancestors before them contended for their own in a land where safety and comfort might often be the reward of cunning, vigilance or speed. And they are suspicious, or pretend to be. The language and actions of the "dude" they do not understand. In fact, they usually pride themselves upon not comprehending his meaning. 


\section{The Black Swans}

And probably experience has taught them that their own way-which they, like some of the rest of us, dearly love to have -is apt to be the best way, at least for themselves.

To begin with, they are "broken" literally, not figuratively, speaking. As colts big enough to be bitted, they will not surrender their native inborn love of liberty, their right to run the range without restraint, until conquered by a force they are incapable of indefinitely resisting-such as Ray, for instance, at the end of that long and merciless rope. They are subjected to the gross indignity of the saddle only by the exercise of brute force ruthlessly applied. And a game fight, too, the best ones make before they sue for peace, and in the case of the more indomitable spirits among them, they accept their bondage with a well defined mental reservation. Some of them have therefore to be "broken" all over again now and then. Ray is quick 


\section{Smoke of the H-F Bar}

to detect the first signs of insubordination in the ranks, and enjoys nothing better than bringing a rebellious subject helpless to his knees with that rope which every member of the devoted band knows only too well and fears.

I have said the ponies are suspicious. Some of them evidently know the old Greek fable of the Wooden Horse on the plains of Troy. They have a wholesome dread of people displaying an affection which your true bronco believes in his wild heart to be but mere pretense. This I have seen clearly revealed by the expression in the eye of a genuine child of the equine wilderness when some animal-loving individual caressed or petted him. Suspicion in every glance! They know better! Some evil intent, some plot against their comfort, is certainly impending! They are glad when the ordeal is over, and breathe freely once again.

They may shy unceremoniously at a bit of paper or any little thing seen 


\section{The Black Swans}

along the trail that is not strictly speaking a part of the accustomed landscape. Nothing of this sort escapes the more acute among them. Indians cannot read "signs" more accurately. All sorts of frightful-looking natural objects such as might well throw a high-mettled Kentucky gaited saddler into fits, are passed by unnoticed. They know all that of old, but if anything lies in their paths that was not there the last time they passed that way beware! Even a stone out of its usual place does not escape them. I had quite an argument one day with Smoke, reliable as he was, on this latter subject, and he had me well backed off under the alders by the ford before spurs vigorously applied induced him to admit that it might be safe for him to proceed, which he finally did with a defiant snort.

Riding in the open the ponies go confidently ahead - Indian file of course. They know nothing about 


\section{Smoke of the H-F Bar}

traveling abreast. The trails they know best do not admit of that sort of progress even if they knew how, which they do not, and the lead pony is the scout that scents all danger for the party. Those that follow at his heels have little concern as to what lies on ahead or 'round about. They know that if a lion, or a twig bent the wrong way, looms up to devour them, the head of the line will be the victim, so the rest may go to sleep in safety. It is when your trail leads you into thick high grass or any close-set brushy growth that a wise cow pony becomes most alert. His ears and eyes are all attention now, and he takes no pains to conceal the fact that he is not enjoying it a little bit. In fact, he would rather scale a perpendicular granite wall, and at great expenditure of effort go well around this hated cover with its unknown risks, than dare the dangers which he consistently insists are lying in wait within. 


\section{The Black Swans}

In common with all the rest Smoke would of course be called rough gaited by eastern riding-masters. Still his trot was not bad, and, when in the mood, he could out-walk most of the company, especially when headed home. They all have the corral and the hill pasture at the ranch ever in their craniums. The return trip is therefore apt to develop into a rattling race, and when Smoke breaks into that gallop it seems to me, as his heavy hoofs come down, that every foothill, every towering mountain from Cloud Peak to Castle Rock, fairly trembles beneath the shock.

Dear old "Smoke!" I can see him now! Buck skin with black points, trained in all the tricks and turns of the cattle "round up," steadfast, sturdy and sensible-at least from his own eminently practical viewpoint-he did the best he could with the handicap he carried to make one visit to the $\mathrm{H}-\mathrm{F}$ Bar an experience long to be remem- 


\section{Smoke of the H-F Bar}

bered. More socially inclined than many of his mates, I think that towards the last he began to know that I at least was not necessarily hostile, for he not only did not resent friendly advances, but in those late August days upon the mountain sides when he and I were often all alone up there between the earth and sky he sometimes came quite close unbidden. And one day at "The Chimneys" we found

\section{Our Lady of the Silences}

[Lines inspired by a remarkable rock formation seen in the Big Horn Mountains of Wyoming, August, I9I7]

Cast in granite, clad in majesty,

Changeless, immutable as the Titan hills

On which thy gaze forever eastward rests,

Enthroned on high with trackless forests at thy feet,

Dumb witness thou through centuries

Of all the miracles that mark

The advent of the darkness and the dawn,

Steadfast alike through wintry winds and fervid suns,

The secrets of the stars and storms are thine, And 'round thy riven rock the lightnings play.

[ 85 ] 


\section{The Black Swans}

No sounds of earth or air or sky

On those Olympian heights

Disturb thy timeless vigil.

Blind to the passing of the circling years,

Deaf to the voice of birds or beasts

That come and go; ye know nor care not whence

Nor whither;

Yesterday, today, tomorrow; all as one to thee;

What is thy mystery?

Far down below thy lofty crag a smiling valley lies,

Here, midst the nodding ferns,

Where dainty wild flowers blow,

A swiftly speeding crystal stream

Nursed by eternal snows,

Flows through green fields that skirt a trail Men say leads on to Paradise.

Here, on a mossy bank, one golden summer day,

One weak and heavy laden came to rest; And by the cooling waters of the limpid brook, Pillowed upon the loving lap of dear old Mother Earth,

With face upturned toward the azure vault,

Thy noble figure, faintly limned at first,

Burst on his view,

And slowly taking, form against the blue

[86] 


\section{Smoke of the H-F Bar}

At last stood forth revealed.

And in the presence of thy dignity supreme,

And in the story of thy resignation, writ in rock,

Was born a thought:

"Like unto thee,

Thou silent priestess of the mountain pass,

Guarding by night and day the way to higher paths,

My soul is set as stone in adoration adamant; Set by some Power whose ways we know not nor can stay;

Set, even as thy graven face is set,

Towards visions fair as rosy-tinted morn,

And doomed like thee

To see the hope that's born anew each day,

Fade far away each night.

"Still shall I watch and wait like thee

Dwelling in solitude immeasurable as thine,

Faithful and true to my ideal,

Until the striking of the hour when I shall heed

The sunbeams and the pale moon-rays

And clouds that shroud a fading world

As little as dost thou." 



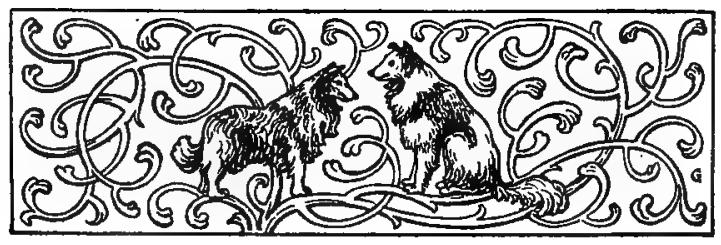

\section{CHAPTER VII \\ Told in the. Firelight}

SPEAKING of fires, we had one on $\boldsymbol{N}$ the rocks for two successive nights way up in the higher range that was a campfire sure enough. We were on a three-day trip to Little Frying Pan Lake where the mountain trout are so plentiful and friendly that they swim between your knees as you stand there in your "waders" begging you to take them first instead of casting farther out. I knew almost as much about flycasting as Smoke knew of Sanskrit, so it was well for me that Lake Frying $P$ an trout were so utterly reckless. As it was I beat the surface of the water so effectually in my efforts at learning how to throw a fly that 
I drove fish by the school into Clifford's basket. He couldn't cast fast enough to accommodate the game I threshed his way. After landing a few by main strength and awkwardness as against mere skill, I succumbed to the heat and mosquitoes and went ashore, for was Smoke not there and Ed, good guide, unequaled cook and general manager? And up above did not the snow-filled gulches beckon? I had often seen the whitetopped peaks, and had half believed it possible that it was really snow they carried in spite of the torrid midday temperature at lower levels, but I now made up my mind to find out for certain on my own account, and soon we were on our way. Yes, it was snow all right, for we scrambled over it, and up above alongside the giant boulders of the peak the blue forget-me-nots were blooming in what seemed up there to be an April sun and atmosphere. 


\section{Told in the Firelight}

Camp was reached at sun-down. The supper a Lucullus feast! A cloudless night; in fact, a night above the clouds came on, and, as a full moon shed its glory over all, the logs and stumps and boughs of pine and spruce and fir, piled high upon the rocks, soon flashed their flaming message to the skies. And by and by the fire burns low. The coyotes are barking down there where the ponies graze, and a story of the West that is no more has forced itself upon me.

The round-up at the Seven Pastures and another we had subsequently seen had been among our late experiences. Old-timers like Burnett and Hess over there near Buffalo will tell you these are but tame affairs in these degenerate days, but still they are not altogether wanting even now in interest. The various participating outfits have the cattle well in hand gathered from the four quarters. Some have already reached the appointed place, and way 


\section{The Black Swans}

off yonder in the north or east or south or west a trampling host of Herefords and Shorthorns come a-trooping down the hills, a solid mass of beef upon the hoof. They are so far away at first they seem mere specks upon the horizon, but as they come nearer and nearer you can distinguish forms and colors. Everywhere the unmistakable badge of the hardy, red-robed, whitefaced Hereford! The cows with youngest calves come last. Some of the babies, weakened by their journey from the far-off pastures, sank at once when the herd was halted. Pandemonium reigned. Many a mother had been separated from her calf, but the bawling of the cows was music to the ears of the man who counted a good crop ready for the branding. You know the rest.

We sat there in our saddles and watched the horned hundreds as they passed; and in the long parade I saw one poor old cripple with the roan coat 
of the Shorthorn, the white face of the Hereford and the great wide-spreading up-turned horns of the old-time Texan. Obviously she embodied within herself the whole story of the western cattle trade; the passing of the red men and the buffalo, the first great invasion of the wilderness by the southern Longhorns, the frightful losses suffered in the early days and the subsequent reoccupation of the ranges under better control and management. All this and more was now recalled by the smouldering embers of our dying camp fire in the mountains, and some lines* I once had written now came clearly back:

* Publisher's Note.- Some years ago Mr. Sanders prepared at the solicitation of leading western ranchmen and cattle breeders a volume of about 1,000 pages which he called "The Story of the Herefords." This bit of verse was added as an appendix to that work, which is highly technical in its character and naturally makes little appeal to the general reader not interested in the subject matter. Many of the author's friends have asked that "The Coming of the Cattle" therefore be printed now in some shape where it would be generally available. Hence its incorporation in this sketch. 


\section{The Black Swans}

\section{The Coming of the Cattle}

Ever as the evening shadows

Deepen o'er the plains and prairies,

Ever as the darkness gathers

'Round the foot-hills and the mountains,

In the fire-light there are phantoms,

In the pine-trees mystic murmurs,

Spirit voices calling ever

From the land beyond the sun-set.

There is moon-light on the mesa,

Stars are shining o'er the sages,

And the night-wind from the desert

Bears upon its wings the wailing

Of the red men in their lodges,

Of the dwellers in the cañons,

Of the children of the vegas,

Of the bison on the meadows,

Of the grizzlies in the gulches,

Of the wolves upon the barrens;

And forever in the gloaming

As the Great Bear watches o'er them

Can be heard their plaintive story

Of the peace upon the ranges,

Of the fatness of the grazing,

Of the plenty in the valleys,

Of the shelter in the forest

In the days before the coming

Of the pale-face and the cattle. 


\section{Told in the Firelight}

Countless moons had passed above them,

Nature's creatures of the dry-lands,

And their comrades of the high-lands.

Generations came and vanished;

Still there came naught to appal them.

Feared they not the fangs of winter,

Nor the flaming breath of summer,

For the north-wind was their keeper

And the south a loving mother;

And the wandering breezes told not,

And the rippling rivers sang not

Of the evil days impending.

But the thunder clouds were hanging

Heavy o'er the hapless races.

Moons of plenty shine not always,

Bluest skies at last are blackened,

Lightnings hover in the sunshine,

Longest trails must have an ending.

And there came the day of waking.

Signs portentous in the heavens,

Fires by night and clouds at noon-day,

Told of trampling hosts advancing,

From the distant Rio Grande.

Hoofs were heard along the Brazos,

Horns were tossing on the Pecos!

From the far-off southern pastures,

From the waters of the Concho, 


\section{The Black Swans}

From the grassy realms of Texas, Day by day in countless numbers Pressed the cattle to the conquest. Northward, westward, ever northward, Toward the sunny plains of Kansas, Toward the walls of Colorado.

Night by night their bed-grounds found them

Nearer still and always nearer

To the nameless unknown perils

Of the Northland they had entered

On the trails that led not backward.

Not the pangs of thirst nor hunger,

Not the northern storm-cloud's warning,

Not the stampede in the darkness,

Not the seas of fire that threatened

On the wind-swept blazing prairies

Stayed them in their great migration As they journeyed ever onward Toward the sand hills of Nebraska, Toward the Bad Lands of Dakota, Northward, westward, ever northward.

And the Chinook came to cheer them. Higher still and ever higher Newer pastures bloomed and beckoned. Where the Yellowstone was flowing, Where the wide Missouri wandered, Where Montana's peaks were gleaming, 


\section{Told in the Firelight}

Where the Big Horn dreamed of battle,

Where Wyoming's highest ranges

Led up to the lofty passes,

To the parting of the waters,

Came the cow-men and their cattle,

Came the bronco and the buster,

Came the camp-fire and the cabin,

Came the round-up and the branding.

Where the silent snowy summits

Guard the Colorado's sources,

Where the darkly-frowning forests

Hide the Rio Grande's fountains,

Lo, the west wind came a-sighing,

Came a-telling of the coming

Of the cattle to the empire

That belonged to Montezuma

In the days before the Spaniards.

Told of hoof-prints of the Longhorn

And of lowing herds a-basking

In the sunshine everlasting,

Where the antelope and bison

And the cliff-men of the cañons

$\mathrm{Had}$ for ages all unbroken

Roamed and reared their happy children.

Vainly had the dread Mojavé,

Vainly had the high Sierra

Stayed the coming of the cattle

On the trail of Coronado; 


\section{The Black Swans}

For they failed not in their daring

Till beyond the burning desert

Far beyond the jagged sky-line

In a flowery land and fruitful

Billows beating on the sand-dunes,

Thundering on the rocky headlands,

Marked the ending of the grazing.

From their ancient haunts the hunted

Creatures that the wild had nurtured,

Driven from their lands and waters,

Now in sullen stealth retreated

To their secret rocks of refuge,

Calling on their sleeping war-gods:

Prayed that elemental furies

Might be loosed upon the ranges.

And the strangers all unconscious

That the earth would soon be shaking

With the anger of the heavens

Went their way in peace and feared not.

As the eagle from his eyrie

Hurls himself upon his quarry,

As the arrow from the cord flies,

As the lion on his prey springs,

As a wounded herd bull charging,

So the wilderness revolted;

So did Manitou awaken,

Swift to punish and to chasten.

[ 98 ] 


\section{Told in the Firelight}

Through the Northland arctic demons

Rode the frozen ice-bound ranges;

Through the Southland fiery dragons

Scourged the earth with blazing horrors.

Then the drifting to the death-traps!

Hopeless struggling of the helpless!

Herds a-wreck from drouth and famine!

Bleaching bones to tell the story!

As the spear by shield is shattered, As the shore turns back the waters, As the rock resists the torrent, So the wild enforced her mandates, Claimed her tribute of the reckless, Taught the lesson of the ages.

Nature brooks not mad defiance!

But the earth renewed its fruitage. Sunbeams dancing on the ranges, Waters from the purple mountains, Soft airs from the western ocean, Called the grasses from their slumbers, Clothed again the world with verdure. And again the herds were gathered, Not with folly in the councils, Not with blind chiefs in the saddles. Children scorched by fire have wisdom.

On the trails that led not backward Once again the cattle entered; 


\section{The Black Swans}

Once again the herds were scattered

Far and wide across the pastures;

At their head a pale-faced stranger

Staunch of limb and lion-hearted,

From beyond the deep sea waters,

From the distant shores of England.

His the heritage of ages

From the hills of grim Glamorgan;

His the power that was descended

Through the Hereford generations,

From the wearing of the burdens

Of the yoke of heavy hauling,

From a life of toil and travail

In the service of his masters.

Proud the bearing of this chieftain

As he armed them for the battle;

Wrapped them in red robes of courage,

Bound them by the ties of kindred

As of tribes by blood united;

Filled them with his dauntless spirit,

Taught them how to meet privations,

Taught them how to face the northers,

Winter's stress and summer's terrors;

Fought their fight through many perils,

Led them bravely through all dangers,

Grasped dominion of the ranges,

Held them in secured possession,

Brought the cattle to their kingdom. 


\section{Told in the Firelight}

As the leaves fall in October,

As the stream dies in the quicksands,

As the snow melts in the sun rays,

So the children of the open,

Of the mountain, plain and valley,

Fled before the rail and rifle,

Fled before the conquering cattle,

Farther still and ever farther

To the bosom of the river

That is bearing them forever

Through the land of the Hereafter.

The fire is ashes now. Ed has told his last bear story and it is growing cold. The day is done. Our shoes are hid away beyond the reach of prowling porcupines. We seek our sleeping bags, and say "Good Night." Next day we ride away. Back to the little slab-side cabin by the creek.

September now is near. Vacation days are over, and the hour arrives when we must say good-bye to Smoke and other loved companions of the trails. We are leaving on the morrow. The evening star has set behind the western walls. A curtain dark is [ IOI ] 


\section{The Black Swans}

drawn o'er hill and dale. The last long silent hours have come. And all night long a voice that calls to me unceasing through the years is heard; a voice that shall be heard so long as summer breezes stir green leaves and flowing waters gurgle by their willowed shores.

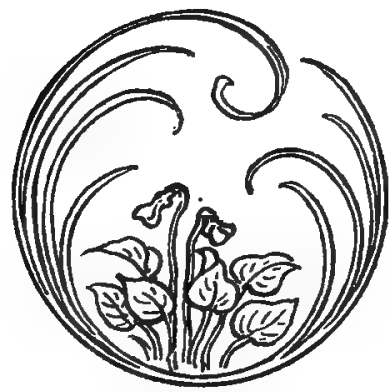




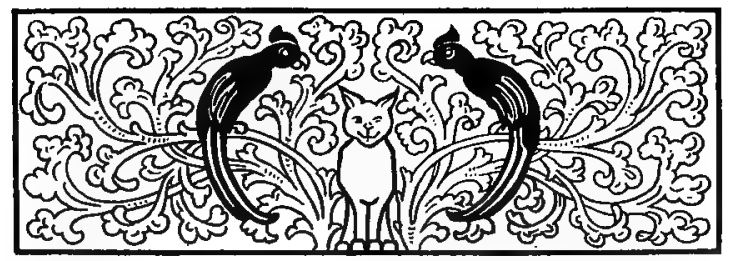

\section{CHAPTER VIII}

"Tick-Tock" Talk

$\mathrm{O}^{\mathrm{N} \text { our return the old clock is wig- }}$ wagging away in its accustomed place just as on the day we left. It has one virtue not possessed by the fire-place; it is always alive and ticking. The hearth cheers only when the temperature outside permits or demands its use. At other times it is a purely negative blessing, loved and valued for faithful service rendered in the past, and prized and longingly regarded for its potential powers and latent possibilities. But the clock will talk to you at any time, and those who have ears to hear its calm and even-tempered comment will find it oftentimes dispensing very sound philosophy. It

$$
\text { [ } 103 \text { ] }
$$




\section{The Black Swans}

seems to have such a serene, contented viewpoint, and when you return from town or from wanderings far afield in quest each of his own particular will o' the wisp it invites attention at once to the fact that many of the best things in life really come to those who only "stand and wait" and bide their time. Why race up and down the world indeed in frantic search of this or that supposed desideratum when all you have to do is to choose a cosy corner in a cottage near an open window where you can see each day and night all that is really most beautiful in all the world? The true measure of all happy hours is peace.

The clock is not the only thing about the place that takes this complacent view. There is an old gray cat there curled up fast asleep upon a soft cushion Billy made for his especial benefit. You could not excite that cat of ours about anything in this world. In fact, he has not even the feline 


\section{"Tick-Tock" Talk}

fault of staying out late o' nights. $\mathrm{He}$ is just a model; that's all you can say about him. And I use that word advisedly, for he was first cast in clay or something, then duly decorated, set in an oven and baked, and lo! behold the best kind of a cat in all this worlda life-size china cat!

I dearly love a good dog, and I have no quarrel with those who may be fond of cats, but to my mind the best cat is like the best Indian. They may be all right around old barns and corn cribs built before this cement age of ours. I suppose they scare some rats away, and now and then get one, but you can get more effective rat and mice exterminators at the druggist's or your hardware dealer's that eat no meat and consume neither milk nor songbirds, so I stand by our china cat. As a living-room decoration he fits in with the clock, and adds a little touch to the picture made by the fire at night. 


\section{The Black Swans}

Yes, and we have some other pets around the cottage. Billy has three birds, a parrot, a canary and an unidentified wood bird not native to these parts. Fortunately Polly does not talk. She just sits up on her perch on the top of a long stick that Billy has stuck into the middle of a basket of palms and ferns with a snake plant in the center. Here again food conservation and other economic questions have had due and, it seems to me, most intelligent handling, for the parrot is a wooden one and gaily painted.

The canary's cage is a rectangular Japanese bamboo creation with arching roof. Billy has painted it yellow trimmed with black. On its tip-top tiny French and British flags are flying. Silk tassels, red, yellow, blue and green, are pendant from each corner. Inside the bird sits in his swinging ring; the outfit suspended from the ceiling by a string turning lazily from time to 
time, from side to side. Now that we have well resolved that we shall no longer patronize distinctively German industries, we do not propose to lend further aid or comfort to Harz Mountain nests, and so our canary is china too! Think of the seed we save! We used to buy it by the bag for a bunch of yellow warblers we once possessed in town. Of course we always have "Jim" Mann's annual congressional donation of packets to help out some, but nowadays these have to go to the sparrows.

I once saw a red bird-the kind they have in Kansas-wired in for the supposed gratification of the inmates of a certain human habitation. I say inmates, because that is the correct term, I believe, to apply to those incarcerated persons who are crazy. Of course no sane person would think of killing thus by inches one of the finest of God's feathered creations. Our wild-wood bird with black tail, [ 107 ] 


\section{The Black Swans}

green back and wings, white breast, black-and-white speckled neck and red crest is usually to be found on the table just back of the big, soft-cushioned davenport standing always invitingly before the fire-place. I don't know just what the ware is called, but it is highly glazed and of English origin, and the bird mourns not lost freedom. The swans of iron complete our present list of household pets.

I am sure the old clock quite approves. If you must have birds, in a country place especially, buy them at any good department store. Leave nests alone. Let the oaks and elms and maples be your cages. They do not crush and break bird health and hearts, and my word for it - a china cat.

I think you have now been introduced to all the members of the household-excepting certain pictures, books and spirits that are an intimate part of life at Dumbiedykes. You see I am 


\section{"Tick-Tock" Talk}

very fond of company; I mean the right kind of company-congenial company-and it is not always with those who talk most that we spend our happiest hours. The clock talks a lot to be sure, but is so quietly unobtrusive about it that it gets not on your nerves. It is the only being I know that can monopolize a conversation-I mean talk all the time, even while you yourself are talking - and not be rude about it.

I suppose there isn't really much excuse for a fire this evening. The doors are open, but the sun is setting earlier these days than it did six weeks ago. There is more time therefore now to use that davenport before paying our final respects for the night to the clock and the china cat. The air in fact is cool, or at least I claim it is. You see I seize upon any sort of halfway plausible excuse to work that Cape Cod lighter. I forgot to say before that one of those inventions of [ 109 ] 


\section{The Black Swans}

the devil, or some ingenious Yankee, which has robbed me of a lot of harmless satisfaction is a part of the general equipment. I have always known that half the fun of building a fire was in tearing up the old "Tribunes" and "Posts," and fussing with pine kindling or some shavings in getting started right, but in an evil hour an oilburning "lighter" came to practically rob me of those privileges. Now we only need a page out of the newspaper and just a few small fagots, and the fire is blazing there before you have had half time enough to get ready to enjoy it. I can thrash the man who thought of kerosene in such connection. It is an insult to my wood, and I object. I prefer to dicker with the sawmill for good slabs to haggling with Rockefeller over his petroleum. But we have it, and rather than quarrel over it we shall use it.

Prodigal as we have been in this country in the use of our natural re- 
sources, great as has undoubtedly been the lavish waste and destruction of our native forests, there is still no occasion to fear complete denudation of our wooded areas if any sort of reasonable conservation be practiced. We may therefore continue to enjoy our open fires complacently. That is one thing among many others that we Americans have to be thankful for.

I have been in at least two countries where it almost seemed a crime to burn wood upon a hearth-Italy and parts of Scotland. The fact is that in Rome or Naples, if you chance to be there in February and call for wood for your hotel grate, you will get a handful of "punk" that responds to your most urgent coaxing only with that languor which we usually associate in our minds with the Mediterranean atmosphere, climate and peoples. In Aberdeenshire the patches of wood you may see here and there upon the granite hills are just "plantations," 


\section{The Black Swans}

all of artificial production. Wood therefore is precious, as are many other things in the North Countrya shilling most of all. In the Lothians or the Trossachs and on Tweedside you will not feel that sense of bleakness that impressed me after I crossed for the first time the great bridge at Dundee en route to Aberdeen to be the guest of an ever-hospitable community. Up there on the western shores of the North Sea (let us no longer say the German Ocean) a thrifty, intelligent and industrious people have wrought more out of little than I have seen produced elsewhere in either hemisphere. Along the coast the deep-sea fishing is an important industry, but it is in the shallow depths of certain stony soils drained by the storied Don, say at Sittyton or Collynie, that you find the most amazing things accomplished. If you care to know what can be made from just turnips (the "neeps" of colloquial Scotch) 
and straw, and perhaps a handful now and then of linseed cake, go into Aberdeenshire, or Angus or Forfar and learn of the simple yet effective processes with which these northern wizards work.

I know that I once lived in ancient Northumbria and afterwards in Scotland, just as I am equally sure that I passed through one former life somewhere along the flanks of the Blue Ridge Mountains. I never visit either that I am not possessed by a sense of attachment, a feeling that these scenes are most familiar and most intensely dear to me. Sometimes I think that I belong there still. I imagine that I could be happy anywhere within sight of Durham Cathedral or in the valley of the Tees or near the Grampians, the Hills of Lammermoor, or on either side of those lofty, rounded, wooded heights that separate Kentucky and Tennessee from the Old Dominion. "The call of the blood," I suppose, this 


\section{The Black Swans}

subconscious knowledge would be termed.

I cannot quite make out the particular location in any case. That is a detail which in the course of generations has escaped me, but there are certain places in that pastoral paradise called Yorkshire that have a strangely familiar aspect. There are rich fields and meadows, rare old trees and ivied walls and high-bred flocks and herds and well-groomed hunters racing down the country-side to the matchless music of the pack-just as in those days of old. I can swear that my ancestors on one side the house were among the ancient Britons who dwelt in Cleveland Vale or perhaps on Derwent Water, and were a part of the migration of those who were pressed out of their fair possessions perhaps in Caesar's time far to the North beyond the Firth of Forth, taking with them that tongue, the remnant of whichthe old "broad Scotch"-is in reality 
the early English of northeastern England, afterwards so thoroughly corrupted by Roman and Norman-French influences. I will take oath that I passed one boyhood on the Scottish Border. It must have been somewhere between Coldstream and Melrose, somewhere between Norham's ruined tower and Dryburgh Abbey's crumbling glories, that I tarried through many a year in some delectable past.

Evidently I am now passing through some sort of transition stage, the significance of which I cannot wholly fathom. I know I was not intended to be harnessed and driven; I know that I resent brick walls, office desks, patent leather shoes, frock coats and derby hats. And yet I have passed a good part of this life within four walls of masonry, and am obliged to wear the clothes prescribed by a Michigan Boulevard tailor. I hate the men's wear of this period. I am not sure that I would go to kilts. In fact, I 


\section{The Black Swans}

know I should not in this climate. And apropos of that, and of the right to bear arms and bare legs, I once had the pleasure and the honor of spending a delightful summer day with the late Sir George Macpherson Grant at Ballindalloch Castle way up there in Strathspey where the heather and the Trojan Ericas were blooming. Prince Ito was there also, but you might not find him quite as interesting as I did. Still he was a bull well worth knowing, whose pedigree may be found in that Scottish bovine Almanac de Gotha, the Aberdeen-Angus herd book. I am sure that His Lordship's "hieland" dress was vastly more comfortable as we wandered up and down the fields that day than were my own long regulation "breeks." Freedom of movement! Freedom of life! Up there in the northern air and hills! And inside the gray old castle walls we climbed the steep and narrow circling steps by which the ancient tower of 


\section{"Tick-Tock" Talk}

defense has been so many centuries ascended; he in garb befitting the environment, the history and traditions of the place. Over the great entrance outside is carved the coat of arms with its warning motto: "Touch not the cat but (with) the glove." Now imagine Sir George or any one else standing on those battlements in 1918 breeches and "bowler" defying mortal enemies under the banner of the Grants of Ballindalloch!

Of course we can't all be Highland lairds, and cling even yet to our ancient blessings and privileges; neither can we who are just over-mind you I said "just over"-the extended draft age don khaki and seek shoulder straps. But it seems to me we might at least be allowed the Greek or Roman flowing civic robes with sandles, or the long loose smock of the English shepherd or Breton peasant.

I think I must be a more or less rebellious subject by nature and in- 


\section{The Black Swans}

heritance. The Scotch were always a stiff-necked generation. Neither the English kings-nor their own sometimes-suited them; and the Established Church they would not abide. And as for my English forbears in the valleys of the Potomac and Rappahannock, they could not long endure the yoke of colonial governors. Anyhow they followed Daniel Boone into. the western wild over the Blue Mountains through dark forests; and had no sooner got comfortably settled in the Ohio Valley when something else went wrong. The trackless prairies called, and in a rough-hewn home of logs beyond the Mississippi the peace and freedom, dear alike to all created things, was found. Maybe it is standing yet, that roof-tree under which a boy once made mud pies and watched wild pigeons in flocks of hundreds gather for the night in the timber by a little stream. Some day I may go and see. That cabin was a cow barn 


\section{"Tick-Tock" Talk}

the last I heard of it-and that was long ago-where four-footed folk found shelter from the storms; where yellow corn and sweet clean prairie hay brought solid comfort and content, where foaming milk pails stood outside the door and expectant cats looked on and waited for a share.

Speaking of wild pigeons-once numbered by countless thousands, but now absolutely extinct on this continent because of ruthless slaughter by thoughtless huntsmen-I once knew a boy who thought he loved to shoot and kill all sorts of birds, but who lived to regret some of his own indefensible acts in that line, and one evening not so very long ago he sat by the evening fire, and there came to him a scene from other days:

Forefend the Thoughtless Deed or Word A May-time of the long ago; A boy and dog a-hunting in the hills 'Midst flowery fields and meadows sweet. The notes of happy songbirds 


\section{The Black Swans.}

Fill the vibrant vernal air

And from a woodland deep

A mourning-dove flies forth.

And if that boy shall live a hundred years,

And if naught else of early youth he shall regret

Whene'er that plaintive spring-time cooing call he hears

That day in May of long ago shall haunt him yet.

A dove lies fluttering, dying at his feet.

Strange, wondrous, iridescent colors come and go

Upon the plumage of a dainty, drooping breast;

Pink changing into rose and purples into violets!

Then all is still.

And when it answered not his touch,

Too late he knew he cared so much; so much!

And thus the thoughtless wanton word

Speeding its cruel shaft

Straight to its mark beyond recall

May crush a love that only winged its way to bless

And throw the pall of darkness over all.

[ 120 ] 
And here I am tonight at Dumbiedykes musing to as little purpose probably as when out there a tired, barefooted, sleepy "kid" once marveled at the whistling whippoorwills when evening came. A slowly burning log that never saw those scenes has brought them back, and why not? These trees from which our stores of wood are drawn may have also harbored in their time many of those self-same birds. It is now some years ago, but once I heard far back in the Clark farm woods near by just after dark the old familiar cry, repeated long and loud not less than twenty times in quick succession, in accordance with traditional whippoorwillian practices. But he did not stay, this courier of the air from somewhere, sounding his message across the space; the one and only call of its kind yet heard at Dumbiedykes. 




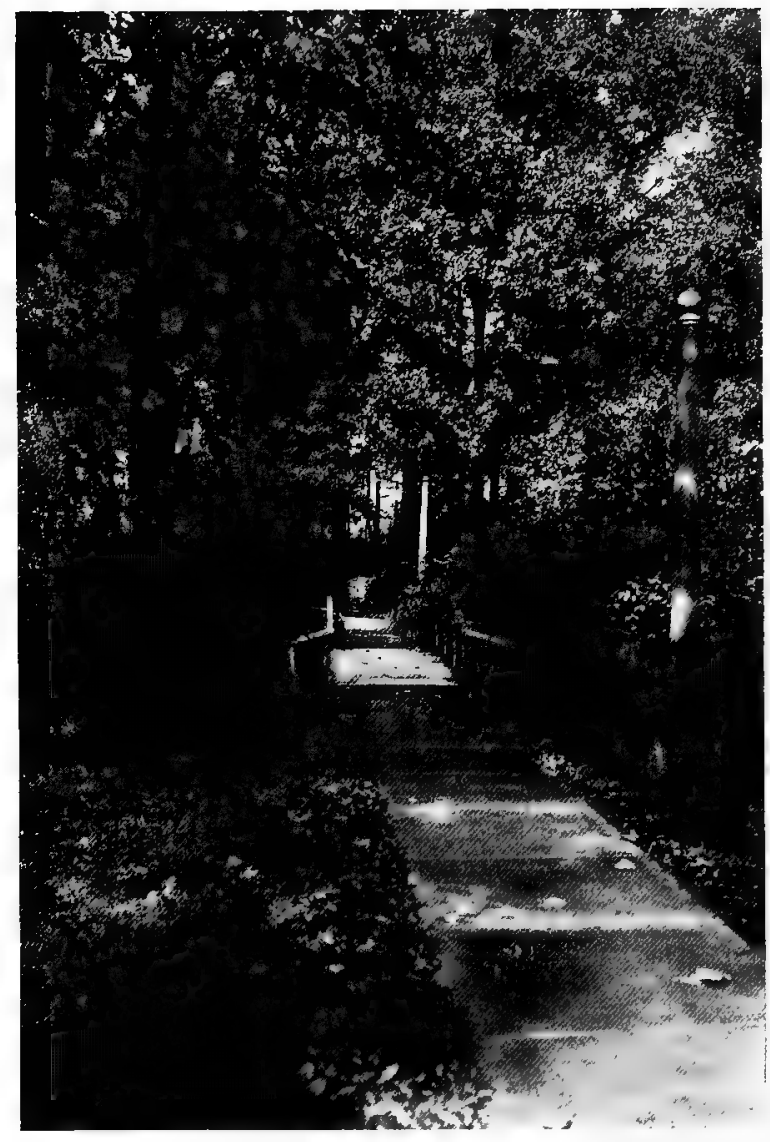

The Wood 


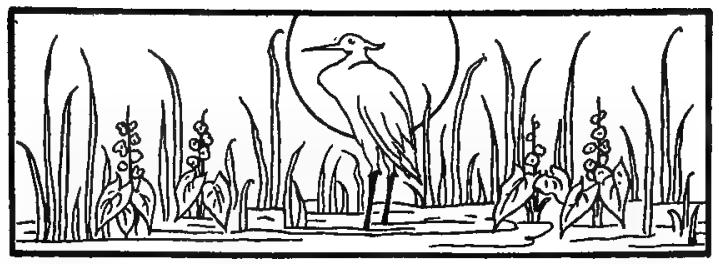

\section{CHAPTER IX \\ An August Night}

THERE may have been bigger, 1 brighter moons seen somewhere, some time, than the one which rose beyond Midlothian Wood the night of August twenty-second, but I doubt it. The curving roadway and the winding walk that led down to the bridge were revealed with almost midday clearness, and underneath the oaks along the fringes of the open glades elusive lights and shadows played. And the night was filled with music.

We expect little of that during the dog days from the feathered folk. They are mostly in seclusion. In fact, the average songbird of this latitude 


\section{The Black Swans}

during these late August days is a sorry specimen. This is especially true of the robins. They are at this period a sad and seedy lot. That cocksureness of themselves so much in evidence in early May has now quite evaporated. The fact is the birds are moulting. They seem to know that they are altogether unpresentable and shun publicity accordingly. You might not think there is so much pride among them, but the truth seems to be that when in this moth-eaten state they seek cover just as naturally as some of the rest of us would under similar conditions. They are neither courting mates nor public notoriety, and we therefore see little of them, and hear less. That yellow-tinted feather lying on the grass there was part of a flicker's raiment only yesterday, and you can pick up a hatful of them if you make a business of it. Certain warblers are already here en route for Caribbean waters, and yesterday a big blue heron 


\section{An August Night}

came along. I don't know what he was doing here nor where he was going. Am not sure he knew himself. We have but faint trace here of marsh or reeds. He was just off his beat a bit, as was also that lone Lake Michigan seagull that shortly afterwards circled and squawked above the links. The bed of the natural surface drainage ditch, called by courtesy a creek, would be dry most of the summer but for the fact that the club long since dammed it where it enters the wood, and keeps it pumped full of water from a deep bored well. In fact, it is damned at some point anew every golfing day all summer; for the best balls used are "sinkers," and if that gull and heron were as fond of hardcoated India rubber as I suppose they are of fish and frogs, they might, if they but knew, feast famously at almost any point where water meets those fascinating fair-ways. But we were speaking of Luna, and I do not 


\section{The Black Swans}

care to dwell upon the subject of lost golf balls anyway. Some people like to joke on facts. Very well. Let them. I prefer to forget some things.

We had been dining at the clubhouse, this night of the cartwheel moon, with George. Know George? $\mathrm{He}$ is a Connecticut Yankee lad of uncertain age, who in his time has worked hard, played some, helped a lot of people and will be here still, I hope and fully expect, golfing, gossiping, dining, laughing, and making one or two new friends each day, until on Judgment Morn they throw him down and force an exchange of his "knickers" for a robe with wings, and make him play with harps, not mid-irons, through Elysian Fields.

It was about nine o'clock when we started for the cottage through the wood. Some say madness lurks in moon-beams. Not being an alienist I cannot discuss so technical a psychic point. I will assert, however, that the 


\section{An August Night}

supernal quality of the lunar flood this August night might almost breed distraction in any mind that has an established touch with the Infinite. It brings one so very close to the unfathomable. It is a manifestation of the working of the same unerring Hand that flushed with rose-tints all unthinkable that filmy veil of vapor overhead the evening of the last new moon just after the sun had gone-a cloud, such as had not been set before I think in any sky, that seemed to turn, as Dumbiedykes was neared, into fleecy flaming wreaths of fire.

But after all I like the dark nights best. A full moon is such a rank monopolist. It dominates all heaven and earth. You can see and think of little else. You get too much of the world and not enough of heaven. The day-time is the earth-time. The nighttime is the sky-time. I know that the face of that fair lady shining so brilliantly up there from out the lunar 
landscape is radiantly beautiful, but give me the moonless, cloudless night with all its million mysteries. I do not want Libra put out of business even for a night, because that is the zodiacal sign under which somebody says I was born. I did not say when. But it was quite long enough ago. I am no astrologist, but I have sat many times in that big solarium at the South Shore Club, and admired that ceiling decoration, even though I don't know anything about the zodiacal signs. I have heard it said that Libra people are temperamental; that they enjoy intensely and suffer correspondingly; that they are mercurial; easily carried up to most ecstatic heights and just as easily plunged into the blackest gulfs. That they are gifted (or cursed maybe) with much imagination. That they are apt to be idealists. That the $\mathrm{X}$-ray power of divining beauty hidden to many other eyes is theirs. That they love art in every form, whether 


\section{An August Night}

it be in the coloring of the petal of a flower, the pictures in the clouds or mountains, the symphonies of the sea or forest. They are apt to try to give expression to their inmost thoughts. Fond of Nature, they find their greatest joy in creating, if they can, something that did not exist before. They are happiest when those who love the same things that they love are sharing with them a great play or opera, a wonderful painting, a poem, an April shower, a field of waving grain, a garden of roses or an open fire.

The star-vault's placid beauty all is lost when the moon-queen rides, and I like the jeweled Pleiades. I miss Antares, too, and all his Scorpion crew. And, so I say again, I like dark nights; even the starless ones, if fields be brown and the roof-tree shakes big rain-drops on the shingles overhead.

As I was saying, we had dined with George, and when we started down the walk, that night of the record moon, 


\section{The Black Swans}

the woods were ringing far and near with the endless eerie trilling of the August "choir invisible"-the socalled snowy crickets of the trees. I wish that some one could or would coin a word or phrase that would convey to the minds of those who may not be familiar with the sound some adequate conception of the quality and character of this strange insect's all-night song. Hawthorne calls it "audible moonlight." A clever fancy that-only the busy band plays on just the same each August night, moon or no moon. Thoreau has spoken of it as "slumbrous breathing." Scudder has located the note on the musical scale as the fourth $\mathrm{F}$ above the middle C. They have a day song too that differs somewhat from that so persistently iterated at night; but that is not so commonly heard.

The "Kates" of course grind out their own peculiar rasping call as the cricket chorus swells from every bosky 


\section{An August Night}

bower, but the "dids" and the "didn'ts" seem to tire of their dispute along towards two in the morning. I suppose they get hot boxes by that time, and have to stop until through the subtle processes of nature enough synovial fluid is evolved to enable them to resume the friction on the ensuing evening. Not so with the trillers in the trees, for when at four I woke and the moon was turning pale in the western mists the air was vibrant still with cricketarian piping, just as when I fell asleep. The male does the work, and apparently just winds up some internal spring and goes about his nightly business, whatever that may be, and the little wings keep going until broad daylight, grinding out sometimes, they say, as high as one hundred notes per minute.

At four-thirty-sun-time, not congressional - they still had the air all to themselves. A stiff morning breeze presently began to blow, and set the 


\section{The Black Swans}

oak leaves dancing, but that made no difference. The shrill cadence still rose and fell. And presently a low and regularly measured note emanating from some other source was audible. At first I could not just make it out, but it was soon brought up with a sudden little jerk, and then I knew at once that it was neither entomological nor yet ornithological in its origin. It was only Billy over there in her nest in the corner of the room softly purring. Luna is fading fast by this time, for the gray dawn is breaking. The crows are cawing, and at fourforty Ben Roberts' young White Leghorn rooster takes a hand. He only learned to crow last week, and doesn't "follow through" exactly yet, but he has found out that he is a sure-enough rooster now, and wants all the world to know it.

At last there is obviously a tired feeling creeping o'er the cricket colonies. There is evident lack of interest, 


\section{An August Night}

or power, after fifty-four thousand separate notes have been produced. Some have evidently gone to sleep or to breakfast, no matter which. A few still "carry on." Then there is a lapse. A few of them come wearily back a little later. Then all subside and switch to the day-time schedule.

At five o'clock the usual performance at this season of the year upon and underneath the awnings at the bedroom windows, is put on. You would say that a turkey or at least a big Buff Cochin hen had somehow landed on the cloth outside and slid with desperate clawing down the steep incline. The struggle for a footing is quite strenuous, but soon over, for the law of gravitation is still operative, and an awning hanging at an angle of forty-five degrees is built for skidding or tobogganing, not for quiet comfort so far as the bird creation is concerned. But notwithstanding the fact that this vain flapping and scratching is 


\section{The Black Swans}

loud enough to be attributed to a much larger creature than a yellowhammer, you will presently see that it is our old friend some call the "flicker" that is going through this morning exercise. But he is not doing it just to keep his muscular house in order. Neither is he doing it for the mere fun of the thing. He doesn't know the first principles of the sport of sliding with Briggs and "Skinnay" down a cellar door. $\mathrm{He}$ only knows that on these cool nights Mr. Housefly and a fat and juicy assemblage of his sisters, cousins and aunts collect around the awnings, or on the wire screening just beneath, as affording a comfortable lodging place; and the bird is hungry, awkward and persistent. You would think that he would scare away at once by his first "descensus Averno" all reasonably prudent flies, but it is not so. The latter are not yet thawed out of their nocturnal numbness, and are easy marks. 


\section{An August Night}

And so the awning slides are repeated perhaps a half-a-dozen times, and may be two or three other foragers will join in the hunt for frappéd flies.

And now the birds have found that when the top of the awning has been cleared they can come in underneath and work the screens. The French windows are thrown back inside the room, so the sport is now clearly to be seen. This morning after the night of the great full moon, with a reference to which this discursive narrative began, two of the birds alighted squarely on the perpendicular surface of the wire netting, gripping the mesh with their needle-pointed claws, and stood there side by side peering curiously and cautiously inside. To me they are silly-looking and queer-acting creatures at best, and their clinging to and climbing up a window screen is about as clumsy and ridiculous a stunt as I have seen in bird-land. There, side by side, the long-billed 


\section{The Black Swans}

pair, glued to the wire, a very picture of discomfort, with piercing eyes, survey the room's interior, plainly trying to figure out what sort of creatures live inside of such a cage. There let us leave them.

All of which is fact, and not an outgrowth of George's dinner, and if you don't believe it ask Billy, for she will also tell you true; she saw them too.

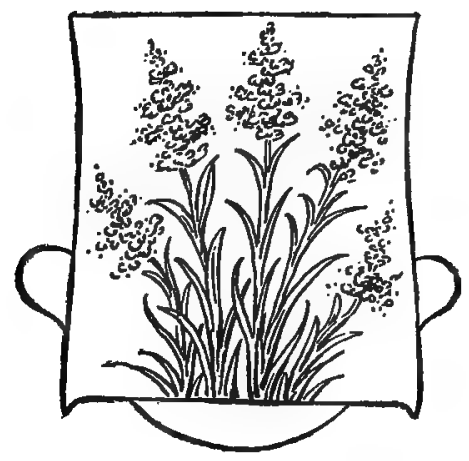





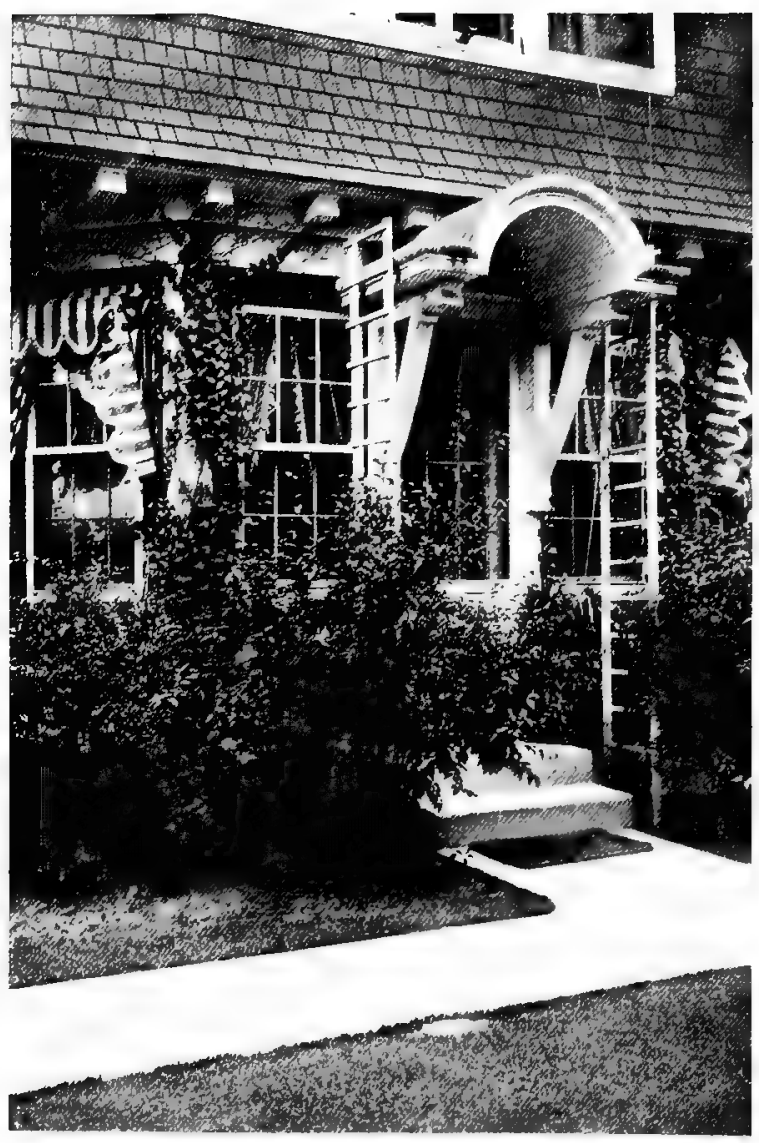

Lilacs AND Ivy 


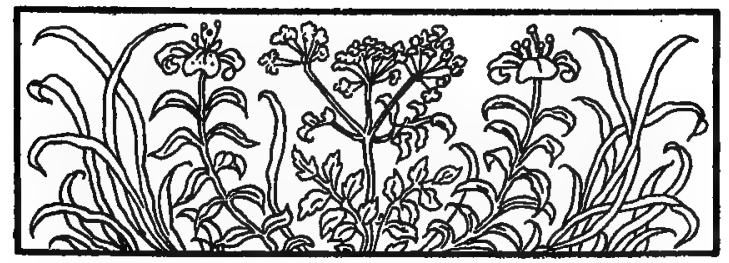

\section{CHAPTER X}

Socks and Flocks

THE "Knit Club" met here today. 1 I do not wonder that there is a world shortage of wool. I have seen acres of automatic looms weaving cloths and fabrics by the mile in times of peace in great New England mills. In normal periods they are heavy buyers in Melbourne, Sydney and London of the fine Merino and Crossbred wools of the southern hemisphere. Our top-makers and yarn spinners have been able to fill but a small percentage of their requirements from the domestic clip. And with the enormous war demands for woolen goods added to the civilian consumption, it is easy to understand why our 


\section{The Black Swans}

old friend George Scott-who in antebellum days played alleged golf at the Midlothian Club-as acting general manager for the American Red Cross at one dollar per annum, has issued a statement from his Washington office advising that the yarn supply for the busy knitters can scarcely be maintained this winter at its past maximum. Just how many hanks have been wound off long-suffering hubby's hands into balls for sock-andsweater-making since the first call was made cannot here be stated. I know that it took, in many cases, a hard-working sheep somewhere a whole year to grow eight pounds in the grease, and that in the scouring this dwindled down to maybe two and a half or three pounds of clean fiber, and I know that if the countless flocks needed to produce these great stores of soft, warm yarns were grazing today in our own country instead of in the Antipodes our people would be better

$$
\text { [ } \mathrm{I} 38 \text { ] }
$$


dressed and more comfortable and our lands vastly richer for the touch of these million golden hoofs upon our soil.

One of the knitters wants to know why then this wool has to be imported. "Why don't our own farmers grow it?" Why be dependent upon Australian "stations" and Argentine estancias? The answer in simple language is that as an economic proposition America cannot compete successfully in the maintenance of the particular type of sheep that bears the special grade of wool required in such volume in the manufacture of the finer fabrics. The sheep that grows this dense fine fleece can and does live upon the scantiest of herbage on great stretches of wild and sterile or even desert lands that have little value for general agricultural purposes. The sheep that is bred in England-land of delicious chops-and mainly in the United States is of a heavier, fleshier 


\section{The Black Swans}

sort, grown primarily for his meat, the wool being a by-product only, and as a rule a longer and coarser staple than the Merinos of Australasia. Notwithstanding the fact that the long and so-called middle-wools find a good market in the woolen trade, and notwithstanding the high prices of lamb and mutton produced by these dualpurpose British and American sheep, still our farmers do not now, and for a long time to come probably will not as a rule, engage in their production. Why?

A knit club can ask more questions in a minute than can be answered in a day. There are several reasons given by our farmers in reply to such queries. For one, the curse of cur dogs. Any worthless canine vagabond, of which there are tens of thousands in the rural districts, can and may slit the throats and worry to their death in one night what it has taken some hard-working farmer-shepherd months or years to 
produce. State laws are being passed as fast as public sentiment will sustain them, designed to abate this everpresent threat to successful flock-keeping. But there are so many fool people who are wedded to their curs that it is difficult to get effective legislation. Fine, well-bred Collies, the old English sheep dogs, and their cousins of France are aids rather than enemies in sheepraising, but in this country, and particularly in the middle West and South, these useful varieties are as yet in a woeful minority.

Again, flock husbandry in the case of the mutton breeds is not the simple pursuit it may seem to the uninitiated. Such beautiful animals as the Southdowns, Shropshires, Oxfords, Hampshires, Cheviots, Dorsets, Lincolns, Cotswolds, Leicesters and kindred sorts are highly artificial products. Neglected, they will therefore deteriorate rapidly. They demand constant care, thought and protection. No 


\section{The Black Swans}

animal is more helpless. None needs closer human attention. And so it happens that many American farmers, especially those unskilled in the shepherd's art, often meet with loss and disappointment. "I have no luck with sheep" is a common expression; meaning, as a rule, that lack of good fortune commonly signifies lack of foresight, lack of knowledge, lack of devotion to the real needs of the flock. A pig can be turned out to rustle for himself. "Root, hog, or die" is the phrase that reflects that proposition. And usually Mr. Porker, whether of high or low degree, whether razorback, Duroc, Poland, Chester, "Hamp" or Berkshire, will root his own way successfully, if necessity compels. Not so the daintier fabricators of the snowy fleece. The delicious roast brown "leg" that you had at dinner last night or the tender chop with the light bone you enjoyed this morning did not come from a raga- 
muffin flock. Toothsome "crowns" or "racks" and rich, thick, easycutting saddles or loins of mutton do not grow on goats or starving sheep.

Good mother's milk must flow in plenty before the epicure may call for "baby lamb." Look at a Dorset matron's generous stores, or contemplate the broad acres of good green rape or cabbages or roots and the bags of cake, and even "sweets," used in the ration where prime product is in the making, and you will realize the labor and expense that lies behind the butcher's block and complain no more of cost.

I don't suppose any of you knitters have been so wildly excited over this prosy talk that you have dropped any stitches. You have knit one, slipped one, purled and narrowed on in the same good old way, and how the socks have grown!

Did you ever eat good mutton off the steaming copper-covered cart at 


\section{The Black Swans}

Simpson's in the Strand? Did you ever feast on"a real "finished" leg in a Scottish border home-say like John Clay once kept near Kelso? Did any of you sit at our own table that time friend Ogilvie sent us a loin and leg from one of a lot of wonderful lambs produced at the Wisconsin Agricultural College farm at Madison? No? Well, Mary knows how to brown a fancy cut of lamb to a nicety; and if the American people at large could once have a chance at lamb and mutton such as the English are familiar with, we too would soon become a lamb-andmutton eating nation, which now we are not-mainly because we have not had a chance at the real thing.

While on this subject, and while you, dear knitters, are proceeding with your work of mercy, and apropos of lambs, I once interviewed the Italian Minister of Agriculture in Rome on the general subject of flock-keeping in the land of the olive, the ilex and the vine. I had 


\section{Socks and Flocks}

a guide or courier while visiting in that country, and used him as an interpreter in the interview of which I speak. I had noticed occasional flocks out on the Campagna and over towards the Alban Hills, and thought to learn something of methods there in vogue. Among other queries propounded to the minister I asked as to how the surplus of the flocks, the annual increase, was disposed of. A reply was quickly given in Italian, but Raphael was obviously embarrassed and at a loss to know how to translate. His English was all right for ordinary tourist purposes. In art galleries or amidst the ruins of the Forum or Pompeii he was quite at home. But a little matter of distinguishing between the ovine male and female brought about in this case a somewhat amusing dénoument. He grinned and stammered as he turned to give me the reply; finally blurting out laughingly, knowing that he was "in bad" from 


\section{The Black Swans}

an English standpoint: "The Meenistair he say-he say-he say-they sell the boys and keep the girls."

A knitter says something about blankets-cotton ones-and this recalls a well-guarded remark once made on a Southern Railway Pullman by a certain New York City girl in reply to a query put by her companion. It was their first trip to Dixieland, and many of the sights and scenes possessed for the young ladies all the elements of genuine novelty. Passing a field in which long rows of little brown bushes bore small white balls just ready for the pickers, one asked the other, "What is that growing there?" And after a moment's study came the safety-first reply: "It is either wool or cotton, I am not just sure which." And the answer seemed to satisfy; and some very intelligent people have trouble of the same sort in our drygoods stores when examining certain modern fabrics. 


\section{Socks and Flocks}

Billy is "pig knitting" at the moment. That is what the other "girls" call it. She has knit herself to a frazzle on socks. They were fearful and wonderful at first. In fact, the original pair came out so huge they were hung on the mantle-piece last Christmas, and when Santa came down the chimney that night he fled dismayed. At least he left nothing in them. There was not enough in his pack to make a show. Later on, however, she had better luck, and I am ready to maintain that few fancier or better knitted socks are now finding their way to France than those from Billy's busy needles. But she is now making me a sweater, and when you make things for any one these days not in, over or behind the trenches you are classed with the Chester Whites, as a very selfish individual.

There is not nearly so much "pig knitting" going on these days in any line of human activity in this country 
as could be seen on every hand a few years since. We are living a little more now for others, and not quite so much for our own selves. I know a marsh not far away were snow-white lilies have found their way to the surface from forbidding murky depths. There is good of some kind, it is said, in everything, even war; only sometimes, try as we may, we have real trouble finding it.

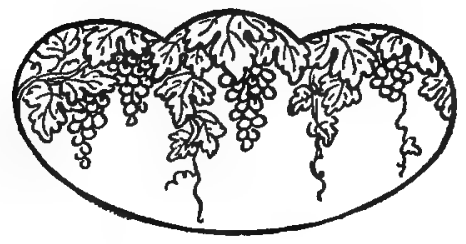




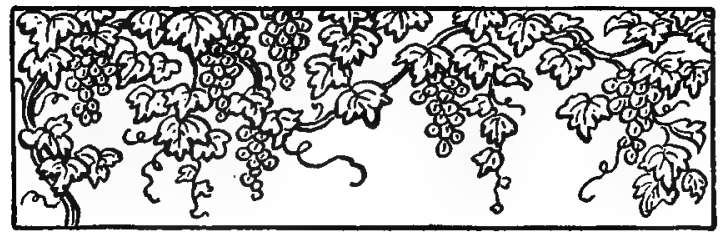

\section{CHAPTER XI}

The Pig in a Poke

\section{BLUE ISLAND! Sounds inviting, $\boldsymbol{B}$ doesn't it? Makes you think of} some sequestered spot were limpid waters lap a pebbly shore and ferns and wild flowers blow. Don't let your imagination play you any such tricks, however, in this case. Blue Island is our nearest post and market town, and has no grottoes-that I know about. I don't think that even the oldest inhabitant could tell you whence, or how, or why the town came by its name. A young lady living in a distant state with whom we had correspondence, but who knew nothing of the town's location or surroundings, was invited once upon a time to visit 


\section{The Black Swans}

Dumbiedykes. She had addressed her letters as usual "Care of the Midlothian. Country Club, Blue Island, Ill." Now she knew that there was a big lake near Chicago, and doubtless had visions of being met by a motor boat or yacht or being taken aboard a steamer plying between the city and her destination. Imagine her surprise, therefore, to find that we were not on an island in Lake Michigan at all, and that Blue Island was neither blue nor surrounded by water. Aside from those two facts she found no fault with the choice of name. And speaking of that I am reminded of the case of Atlas.

Down in Pike County, Illinois, in the hills flanking the great wide Mississippi River bottoms there are, or were some years ago, the remnants of a hamlet that rejoiced in the earthsupporting name of Atlas. It consisted mainly at the time I first passed through it of a tumble-down blacksmith shop with the inevitable flotsam

$$
\text { [ } 150 \text { ] }
$$




\section{The Pig in a Poke}

and jetsam always cast up around such places by a farming community. Ramshackle buggies, old wagon wheels and parts of plows or harvesters rusting in the weeds; just a "shack" or twoall that was left to tell the tale of anticipated greatness unfulfilled. It seems that Atlas is, or was, one of the oldest towns in central western Illinois, and its story is so similar to that of a thousand others in the Middle West that a little anecdote of its founding will perhaps appeal to those who may know of like instances of buried hopes. I know that the town in Iowa near which I happened to be born shared the same fate as Atlas. Indeed its name was long since dropped out of the official Postoffice Directory. But we speak now of Atlas. Its location had been decided upon by the pioneer land investors of the early days when emigration was streaming over the flowery prairies of Illinois, with the Mississippi or beyond as the objec- 


\section{The Black Swans}

tive. The site selected for "the future great" commanded a wide view of magnificent sweeps of black alluvial soil, and on the uplands the bluegrass that promised rich for pastoral husbandry ran riot in the hills. It looked good. It was good. There were no settlements with any particularly promising prospects for leagues and leagues in any direction. A name to fit its manifest destiny was chosen, surveys were made, the first buildings erected and in fancy its fond founders saw in its embryonic state the coming metropolis of an empire rich beyond all dreams. The empire arrived in due course all right, but not so the hopes of Atlas.

One day word came to the village fathers that some hare-brained settlers a little farther up the river had staked out another town, and it was to be known as Quincy. While this created no particular flutter in the expectant streets of Atlas, a meeting 


\section{The Pig in a Poke}

of the bewhiskered candidates for future aldermanic honors was nevertheless held that night in the corner grocery to discuss the matter; and over the "navy plug" the relative prospects of the two communities came up for argument and adjudication. Those few faint-hearted ones who manifested any doubt as to the assured supremacy of Atlas were soon silenced, and before the court had adjourned it had been unanimously determined, once for all, that "Quincy never could amount to a damn anyhow, because it was too near Atlas!" Alas, poor Atlas! you know what happened to her; or rather you know what happened at Quincy, where one of the West's leading railway systems built a great steel bridge and shops and made a thriving city, while Atlas withered and decayed until finally one day a strong wind blew it off the map. One of a thousand similar victims of pioneer railway engineering. 


\section{The Black Swans}

But we are forgetting Blue Island in our contemplation of Pike County's tragedy. An island used to be defined in my old school geography as a body of land entirely surrounded by water. The only water in or about Blue Island is that which flows through big iron mains beneath the pavements, and along the bed of a creek called the Little Calumet, soon to be utilized as a part of a big drainage ditch. While near the great city it is not the conventional suburb at all. On the contrary, it has a past of its own; an existence and individuality of its own and certain institutions of its own to which its inhabitants and those of the country tributary to it cling with the traditional tenacity and conservatism of people of their race-old countrymen mainly of German peasant derivation. For instance, at stated intervals, by and with the consent and co-operation of the town authorities,' a genuine old country street fair is held, upon 


\section{The Pig in a Poke}

which occasion the south end of the main thoroughfare presents a scene with which few of the present generation of Americans have any familiarity.

"Fair" day is a real gala day in this community. From early morn till dewy eve the trafficking and gossiping and beer-getrinking goes on, and in the meantime a considerable businessmade up largely of the buying and selling of everything you can imagine in the line of farm products from goose eggs to spavined, string-halt horses - is transacted. Itinerant vendors of peanuts, "pop" and pink lemonade establish themselves just around the corner at the crossings nearest the heart of the day's doings. The farm folk straggle into town, some of them the night before, and all the rest at early dawn, and you know when you see the live stock put in offer that you are not dealing with readers or students of The Breeder's Gazette.

$$
\text { [ } 155 \text { ] }
$$




\section{The Black Swans}

Horse trading is the big feature of the fair. Somewhere, some place-perhaps behind the Kaiser's front linesit might be possible to collect a more picturesque lot of lame, blind, crippled, swollen-legged crow-baits than are assembled from heaven knows where on these Blue Island market days. I fancy they do not all come from the farms of Bremen township. In fact, it is not impossible that the Hebrew dealers and the peddlers and the "junkers" generally in the city send out, perhaps under cover of darkness, some of their own most striking specimens in the hope of unloading on somebody at a profit. Gypsies, too, sometimes have a hand in this raffle of equine derelicts. So it is a case of diamond cut diamond, a lottery in which the participants apparently enjoy taking all the chances that attach to swapping and trading in such trash.

While the men-folk are wrangling among themselves over the twenty- 


\section{The Pig in a Poke}

five dollar horses, the women have not been idle. In the old days they appeared in wooden shoes. They practically monopolize the trading in cows, sheep, pigs, geese, ducks and chickens. These are not usually in large supply. In the case of cows, sheep and pigs, single specimens commonly form the subject of the bartering. Sheep are seen but seldom. There are too many cur dogs in the community to make it safe or profitable for any one except a butcher to buy one. The class of milch cows offered would not appeal specially to experienced dairymen. They are of all grades and crosses from just plain knot-heads to an occasional poor relation of the Hereford.

I have often heard the expression "buying a pig in a poke," but I never understood it exactly until the other morning when driving through the fair I saw an animated gunny-sack rooting its uncertain way on the side- 


\section{The Black Swans}

walk near the curb. The pig was not able naturally to make much headway in any particular direction. That of course was the object of this particular form of captivity, and presently the old lady that had the deal in hand effected a sale, after first giving the prospective buyer-another thriftylooking hausfrau-a peek inside the bag. Passengers on the suburban trains making the Blue Island stop are often surprised as the cars speed cityward to hear the squealing of little pigs or the quacking of ducks emanating from somewhere within the recesses of baskets belonging to undisturbed females who have attended the fair. And if you chance to be driving out Western Avenue from Chicago at sundown you will see a long string of battered, bandaged horses straggling painfully onward to their respective destinies, and in and around Blue Island the cows with doubtful udders are being led to village pasture lots 


\section{The Pig in a Poke}

The fair is over. Blue Island bars are somewhat richer for its coming, and a lot of people have got rid of things they did not want or need, and others are in possession of that which they thought they wanted or needed or could turn over at a profit, and no middlemen have come between. Such is the only rival the Union Stock Yards or South Water Street has in Cook County so far as I have seen. I wonder when Mr. McAdoo may wish to take it over.

A bit of the old world transplanted to the new, a bit of the past engrafted on the present, this quaint recrudescence of ancient commerce on the Little Calumet. Probably it will disappear shortly. Soon also will the little stream near by find its accustomed course reversed, and Lake Michigan's waters pouring westward through its bed between great walls of stone. 



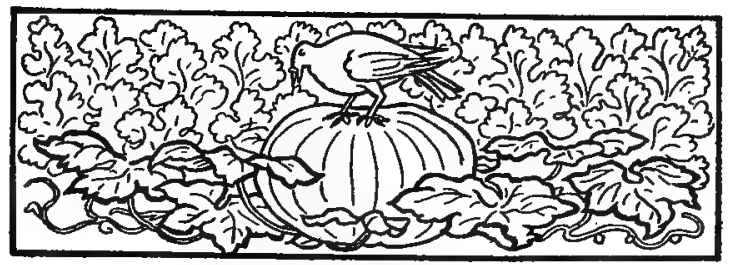

\section{CHAPTER XII \\ A Pumpkin and a Prince}

WHILE on the subject of fairs I am wondering if, after all, the great exhibitions now annually staged by the leading farming states, representing large investments for the proper equipment of an up-to-date agricultural exposition, have so very much on the old state fairs I used to know. Of course they have. To deny that would be to assert that we may not be making progress, and far be it from me to advance any such heretical suggestion.

It has fallen to my lot to acquire familiarity with various important state, national and international presentations of the achievements of those who till the soil and tend our priceless 


\section{The Black Swans}

flocks and herds. It was indeed a far-cry from the little county fair of long ago, when as a boy I helped collect for it our best productions of garden, orchard, pasture and paddock, to the World's Columbian Exposition. It was a long leap from my first Iowa State Fair at Cedar Rapids to the imposing demonstrations of the Exposition Universelle de Paris of 1900. There was some contrast between the first Fat Stock Show I reported on the spot where the Chicago Art Institute now stands and the Royal Agricultural Shows of England I have since attended. But, after all, the difference is one of degree only. The fundamentals are the same, yesterday, today, tomorrow and forever. It is only the setting that is different. The aims, the objects, the purposes, the inspirations have not varied. Then, as now, it was the setting up of standards by which the year's attainments in the primal arts of peace might be truly 


\section{A Pumpkin and a Prince}

measured and compared; the treading of the rich fruitage of the vines, the celebration of the gathering of the sheaves-a custom handed down in various forms through all the generations; and one that shall not be lost so long as men shall sow and toil and reap.

My earliest personal experience as an exhibitor was with a pumpkin. Then as now in some localities it was customary to plant the seeds of this humble but vigorous and prolific vine in the cornfields, and one year as the corn was approaching its maturity one of the hundreds of pumpkins hidden away underneath the rustling blades gave promise of attaining prodigious size. Day by day I watched its steady progress. It looked a prizewinner sure enough, and I claimed the privilege of entering it in the coming county competition. The big Percheron horses and pigs-the latter as good as I have ever seen since-were being prepared for the same great event, but $\mathrm{my}$ hopes 


\section{The Black Srwans}

were for the time being wholly centered in that blessed "whopper" out there in the cornfield. I was so afraid that something would happen to it that I could scarcely sleep o' nights. Somebody or something, I was sure, might break the fragile stem upon which my visions of winning that dollar offered for the best of its kind on exhibition all depended. Early and late I noted with ever increasing wonder and satisfaction the extraordinary belt line of that one great pumpkin of its day and generation. Nothing like it had ever developed before within the range of my very limited observation, and I had a lot of trouble trying to make up my mind as to the particular use to which I should put that dollar.

There were two red letter occasions each year when I never, never had half enough small change available. One was Christmas-time; the other the Fourth of July-saying nothing about circus day. Sometimes I had 


\section{A Pumpkin and a Prince}

managed to accumulate for those rare events as much as a dollar and a quarter, but a dollar and a quarter doesn't go real far when you are in a toy shop every day for two or three weeks before Christmas with the windows and show cases overflowing with marvelous gaily painted tin soldiers and jumping jacks and monkeys that turned wonderful somersaults over the top of a stick! As for the glorious "Fourth," fire crackers cost fifteen cents a bunch and torpedoes ten cents a bag, and if you commenced when the other "fellers" did in the morning and kept it up until near noon you needed a lot more than I was ever able to purchase. How I envied those plutocratic playmates who were able to enjoy the tremendous thrill that attended the firing of a whole bunch of the little red "crackers" all at once! Then lemonade, peanuts and soda water added grievously to these early financial difficulties, especially on those 


\section{The Black Swans}

halcyon days when after weeks of anticipation we trailed the band wagon of the circus in its triumphal tour of the village streets. I usually got inside the tent, and on one memorable occasion had a little change left to buy a ticket for the "special concert to be given immediately after the conclusion of the performance in the ring." Yes; and by some special Providence there was ten cents still remaining after lavishing a quarter on the concert ticket, for which I presently found important use. The clown that day sang a song entitled "Pulling Hard Against the Stream" that for some reason or other made quite a hit in the sleepy old town. We boys as a matter of course were arranging for the usual attempt at holding a show of our own shortly after the circus left, while the excitement and enthusiasm were still in possession of our souls. We nearly broke our necks of course trying to ride a horse bareback standing up 


\section{A Pumpkin and a Prince}

and testing out various acrobatic stunts; and thinking that we should sing something just as "them reg'lar show actors" did, I had spent that last ten cents before the show left town for a copy of the clown's own song book. For some reason or otherprobably because I couldn't walk on my hands or successfully negotiate a big tight-rope-I was picked to sing a song. So I promptly memorized the one that had drawn the most applause at the real circus. That's how I happen to remember parts of it even now. The music was, I suppose, an utter abomination and the lines pure doggerel of the cheapest sort. But it was apparently an appeal to one's better nature, each verse bringing up at the end with a long-drawn-out "S—oth-e-n!" leading into the chorus:

"Do your best for one another Making life a pleasant dream; Help a worn and weary brother Pulling hard against the stream." 


\section{The Black Swans}

Now I cannot say what there was in this that seemed to strike a responsive chord in the breasts of that particular community, unless it was that nobody out there in those days ever seemed to have much money, and being thirty miles from any railroad, only the worst and cheapest circuses ever had the courage to invade it, and I suppose that for these or other equally cogent reasons every boy living there knew in his own heart that he was the particular "brother" alluded to in the clown's plaintive ditty. I know that I for one was beginning to rebel against hoeing potatoes and milking cows in red-hot weather, and envying those favored of the gods whose only duty was to take care of elephants and tear down and put up tents and seats and travel all night to the next town and when the show "busted" get no pay.

But what about that pumpkin? Well, the corn was cut one day and there lay my prize pumpkin of stu- 


\section{A Pumpkin and a Prince}

pendous girth in the mellow, lateSeptember sun in all its golden glory. "They can't beat it," I said to myself, and to the fair it went. And do you know that the fool judges didn't have any more sense than to pass it by and stick the ribbon that carried that dollar onto a fat, heavy, orangecolored globe that wasn't half as big around as my own, and left me brokenhearted! Mine was flat on top and bottom to be sure, but any tapeline in the world would have convinced any committee with the ability to read plain figures and measure accurately that I was clearly entitled to win! And so came, like a bolt from the blue, what still seems to me to have been the first truly bitter disappointment of my life. I have had some other disappointments since, but none that made a more profound impression. And father got his too. A favorite trotting nag of his "broke" badly coming down the home-stretch of that 


\section{The Black Swans}

little old half-mile track and was beaten under the wire by at least two lengths in the deciding heat. After listening to his comment upon that performance, and the unprintable remarks of the trainer who at the critical moment had driven the poor little bay mare off her feet, I began to realize that I was not the only one with a grievance against the world, going home that night a sadder but perhaps wiser youngster.

This incident recalled from boyhood days may serve as well as any other to suggest, even if faintly, the good actually accomplished everywhere by these competitions. Experience is the only school whose lessons are taken home and long remembered. This one taught me several things worth knowing.

There is an old saying to the effect that each crow fondly thinks its own young white; that is, better and more beautiful and more wonderful than 


\section{A Pumpkin and a Prince}

any other crowlets that ever happened. All the other crows know the truth, and sooner or later these doting parents discover that their own progeny are no whiter than their sisters, cousins and aunts of crow-land.

Another thing; the casting of my mammoth pumpkin into the discard at this county fair taught me once for all that mere size, mere stature, mere girth, mere bulk, mere pounds avoirdupois, do not necessarily mean the most quality, and afford no guarantee whatever of superior fitness or desirability. On the contrary, when my big pumpkin was cut open it was so coarse-grained that when chopped into chunks it was not even relished specially by either cows or pigs, all of which simply means that the finer fibers rarely accompany the ranker growths in either the animal or the vegetable kingdoms, and the county fair enforces these and kindred lessons just as effectually as do International Expositions. 


\section{The Black Swans}

Some years after the boyhood tragedy herein mentioned, I attended a show of the Royal Agricultural Society of England held in a field adjacent to the grand old park at Warwick Castle, not far from Leamington. This world-famous exhibition is a "movable feast," not possessing a permanent home and equipment as is the case with the leading American shows of like character; the idea in Great Britain being to bring the benefits of the show home to the very doors of the people in all sections of the country by shifting it from year to year to various parts of the kingdom. One year it may be at Bristol, the next at Carlisle or York, and so on all around among the larger county towns and cities; local assistance being given in each case, with the Royal Society's funds drawn upon for general expense. The Warwick show of which I speak was held under the Presidency of the then Prince of Wales, subsequently 


\section{A Pumpkin and a Prince}

King Edward VII., and His Royal Highness was not only present, but took the keenest possible interest in all its details. I knew that at his own favorite Sandringham the Prince had Southdown sheep and Shorthorns and other useful and admirable types of domestic animals, and that he took a personal interest in them. I was scarcely prepared, however, to learn at Warwick of his intimate knowledge of the breeds and their points of excellence. These wonderful exhibitions of all the finest types for which Great Britain has so long been famous are usually held in July out in the open; temporary stalls with canvas covering to protect the animals from the sun or rains being the only shelter provided. On the opening day I was so fortunate as to meet the Prince in that section of the park allotted to the cattle, "doing" the show on foot incognito, like any other interested visitor, in order to avoid the crowds 


\section{The Black Swans}

that always surrounded him when on official inspection tours. His only companion was Sir Jacob Wilson, one of the foremost agricultural authorities of his day in Britain. I only wish that our American president and expresidents, our senators and cabinet officers, our men of prominence in civic, commercial or political life, could have listened that day to Prince Edward's comments on the animals as they were shown. His interest was not perfunctory, his knowledge not superficial. He knew the cattle as he knew the sheep and horses. He was not necessarily impressed by scale. $\mathrm{He}$ knew correct and faulty conformation. $\mathrm{He}$ was pleased and gratified beyond measure to see such a marvelous presentation of England's pastoral wealth. $\mathrm{He}$ was more capable of judging in the prize-ring than thousands of American farmers even, saying nothing of the conceded incapacity in such important matters among those 


\section{A Pumpkin and a Prince}

who are most conspicuous in the social and pictorial columns of the American press.

I use this case of the late King Edward merely to illustrate a broad national difference of viewpoint in respect to certain things lying at the very roots of Anglo-Saxon greatness. I afterwards visited other Royal shows, and always found the landed gentry, peers of the realm, members of the royal family and government, men whose names were familiar in high finance and public service, mingling with the sturdy tenantry, the herdsmen and the shepherds; and every man knew what he was looking at, and could appreciate quality wherever present. They cherish their well-kept herds and flocks as an integral, a vital part of a great inheritance. They regard it as a duty as well as a personal privilege to thoroughly inform themselves in respect to these truly valuable national possessions, and in the sun- 


\section{The Black Swans}

light of assured patronage and generous co-operation from the highest sources, even the humblest "hewer of wood or drawer of water" in all Britain has constant inspiration to stand by the soil and its choicest products; and so it is that "over there" a reputation for outstanding skill in the gentle arts of agriculture means certain reward and public appreciation, and father hands it down to son as a prized possession.

When John McCormack, the Irish tenor whose voice is loved by millions of Americans, offered his services to the government at Washington to serve during the great war in any capacity the President might deem best, he was urged to sing our patriotic popular songs throughout the length and breadth of the land, and if so disposed turn over the proceeds to the Red Cross. In pointing out the real value of this form of service the President is quoted as having said: "Somebody 


\section{A Pumpkin and a Prince}

must keep the fountains of sentiment flowing!" Woodrow Wilson is an apt phrase-maker. Probably no president since the lamented McKinley has possessed that gift in greater degree, and in these few words he has given expression to a truth, the important bearing of which is not sufficiently recognized by so-called practical people.

One might say that there seems little room for sentiment in the "tending of cattle and tossing of clover;" that there is little place for the play of the imagination in the effort of trying to make two blades of grass grow where only one came forth before. That the evolution of new and finer types of grains and fruits and flowers is an occupation fit for the merely patient plodder only. That the creation and maintenance of choice herds and flocks is a task to which only dull minds may profitably address themselves. Washington on his loved Mount Vernon acres proved the hollowness of such 


\section{The Black Swans}

assumptions. America seems destined now to step into a position among the nations of the earth that bids fair to mean world leadership henceforth. But this should not simply mean possible supremacy in financial or commercial enterprises. Indeed, if in the unfolding of our future, we shall give to history no names fit to match those of Bakewell, Ellman, Tomkins, Cruickshank or McCombie, we shall not have recorded full-rounded progress as a people. These names mean nothing to you? Well, they should; and if you don't believe it, then the next time you come to Chicago pay a visit to the Saddle and Sirloin Club-preferably when the International Live Stock Exposition is in progress-and you may then possibly share with me the belief that not all the great Americans of the years to come-men with brains and sentiment and patriotic impulsewill build their biggest monuments either in Wall Street or in Pittsburg. 


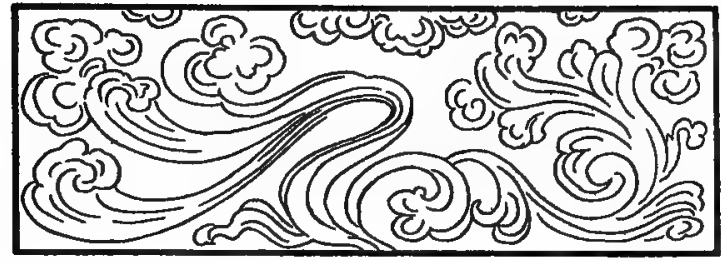

\section{CHAPTER XIII \\ The Flames that Clarify}

THERE are still other fires all 1 normal people like, such as one that I have just helped tend, for instance, the burning of dead vines and stalks and weeds and leaves, the remnants of a garden which for weeks has been a generous provider. How easily the hardened roots release their former grip upon the rich black mellow soil! They know their race is run, and for the most part give up gracefully. A few sturdy ones, however, that I had thought were done with life made a resistance altogether unexpected, but after I had torn and broken down a plant that was not ready yet to go, I knew at once that I had interfered 


\section{The Black Swans}

with some well-formulated plan of $\mathrm{Na}$ ture, and was sorry.

We fancy we know so much more about a lot of things in this world than our common Mother knows. We are always and forever assuming to improve on the universal scheme, correcting the Almighty and his laws, and all the while the All-wise makes of us and all the best-laid schemes of men (not mice) a mockery. We can by force of arms, by acts of parliaments, intervene successfully for a time, we fondly think, with the general plan, but the tables on which men carve their edicts crumble into nothingness, and drifting sands entomb the walls of Babylon, whenever Nature cares to resume the sway she never really has resigned. I had no business pulling up that big Helianthus before its seeds had fully ripened, but that will not prevent some other sunflower from fulfilling its allotted mission. You can't overthrow Nature by taking one 


\section{The Flames that Clarify}

life or blasting one bright hope. You cannot change the leopard's spots by caging him; neither can he change them himself, try in the jungle as he may.

Enough green stuff goes on the autumn garden fire to fill the air with smoke that is both blue and fragrant. What is there in the odor of the burning of dry grass and stems and twigs that makes such wide appeal to human sensibilities? Every small boy knows well what I mean by this; and every sane small boy is enough of a primeval savage to scent in that smoke some far-off simple former life in forest glens.

Do you know that within the city limits of Chicago is one spot where touch with man's natural environment may almost be attained? Here and now I want to pay glad tribute to the man who was wise enough to place in Jackson Park that Heaven-born inspiration called "The Wooded Island."

$$
\text { [ I8I ] }
$$




\section{The Black Swans}

I suppose it may have been Frederick Law Olmstead. He had a lot to do, I believe, with the landscapes now so dear to all who know the former site of the World's Fair of 1893. But whoever did it builded his own great monument, and generations yet unborn will seek the solace of its isolation. No road-way crosses to it. Arched bridges lead you from the busy drives across lagoons in which big forest trees have plunged their roots. The motors and the trolleys are not there. The birds know it well enough. Trust them for that, and squirrels once scampered everywhere until long protection so increased their number that it was found too many nests were being robbed, and they were banished. At least so I've been told.

One day last March when the sun had whispered something to the trees that made the willows and the dogwoods start, I strolled across this Wooded Isle. The grass was showing [182] 


\section{The Flames that Clarify}

faintly green, and through the branches bare the lake winds roared. You see the island at its best, I think, on such a day. November though would do as well as March. The roses will be gone and the summer crowds that frequent it will not be there. But you want the tree-tops bending to the pressure of strong winds if you would hear the organ-chords that fill that silent, solemn sylvan auditorium. And you may be so lucky as to find the workmen burning brush, the trimmings from the trees. If so, the incense rising from those fires will do the rest. And when you turn away and retrace your steps across the arching bridge that sends you back to boulevards, I wager you will almost wish with me you wore old overalls and had to work your way along with axe instead of pen; at least for one long happy day.

If you leave the island by the southern bridge you will see French's majestic statue of the Republic-the

$$
\text { [ } 183 \text { ] }
$$




\section{The Black Swans}

recently erected replica of the one in staff that welcomed the nations of the world in Columbian Exposition days. The fading of that picture is Chicago's greatest tragedy. There flowered the architecture and the allied arts of all the ages; a poet's dream of one short summer night, a mirage too beautiful, too evanescent to really exist save in imagination. But it served its splendid purpose. Its profound, refining influence upon a people none too familiar with "the beauty that was Greece," the "grandeur that was Rome," and, may I add, the inspiration that is France, long since became a prized national possession. Only a trace of the grand aggregation of palatial structures now remains. The Fine Arts Building alone of all the exhibition halls was temporarily preserved. A great fire swept away most of them, thus saving a laborious demolition by hand labor. And the Art Hall's days are numbered. 


\section{The Flames that Clarify}

Strictly classic in spirit and outline, its crowning feature the low-set dome copied from the Campo Santo in Genoa, it is slowly but surely falling into ruin, and, when the Field Museum is finally completed downtown, the old Columbian relic's last days will have come. Rabida and the caravels are still with us. The German Building is still permitted to stand near the lake, and a little north of that the old Iowa state pavilion may still be seen. Upon the Wooded Island the quaint artistic contribution of Japan yet bears its testimony to the skill of the artisans of the land of Fusiyama and the cherry blossoms. A soul-inspiring marshaling of the resources of a world at peace, this celebration of the four hundredth anniversary of America's discovery. And as I write, the city by the lake is opening the gates upon a very different scene. The Government is showing to the people of the Middle West a glimpse of what is meant by war- 
the war that means the re-birth, the re-consecration of America. And this brings vividly to mind that there are other fires that differ from all others herein mentioned; the sulphurous flames of Hell itself let loose by one man's hand without so much as "by your leave" from subjects blind to their own misconception of their destiny and deaf to the voice of liberty and law.

It seems not very long ago I made a daily official call at the United States Government Building on the Rue des Nations on the banks of the Seine, in the heart of Paris, while the last of the series of Universal Expositions held by the French was in progress in $\mathbf{1 9 0 0 .}$ The world was not yet disillusioned. Germany was there our neighbor on one side, and Italy on the other. Around the Champ de Mars were grouped the buildings that housed the products of the arts and industries of every clime; a brilliant artistic triumph

[ 186] 


\section{The Flames that Clarify}

of French genius, with the flags of all the nations overhead. The flowering of the chestnut trees in May had ushered in the great event with the music, pomp and pageantry of peace. Picard and Delcassé gave gracious welcome in the name of France around the rich Elysée Palace banquet board. There was no thought in any mind, save one perhaps, of Verdun or of Vimy Ridge. The German High Commissioner was there, but made no reference to Louvain nor Liège. The Russian prince that sat upon my left that night spoke not of Lenine, Bolsheviki nor Trotsky, and on a certain other happy day at St. Germaine there was no mention of the Marne. The Bois was gay with pleasure-seeking crowds by day; the Champs Elysées gleaming fairyland by night.

It is hard to conceive the changes that these eighteen intervening years have wrought. It is difficult to understand how those fêted guests so warmly 


\section{The Black Swans}

welcomed to that concord of the nations from beyond the Rhine could even then be plotting the hurling of unheard-of giant super-shells from fifty miles away into the very shadows of Notre Dame itself. Thank God for Joffre, Haig and Foch, and for our Pershing, and for all their men! May they never sheath their swords until those flags of nations once I saw along the Seine are streaming yet again together in the sky, this time above Berlin, with that of Wilhelm unter alles.

The garden must be cleared forever of that noxious weed, unbridled power. The poison ivies of the Prussian wood must be consigned to all-consuming flames. Then, and only then, can our children, and our children's children, go out in safety through the world to pluck the fruits and flowers that grow along the paths of peace and honest toil. 



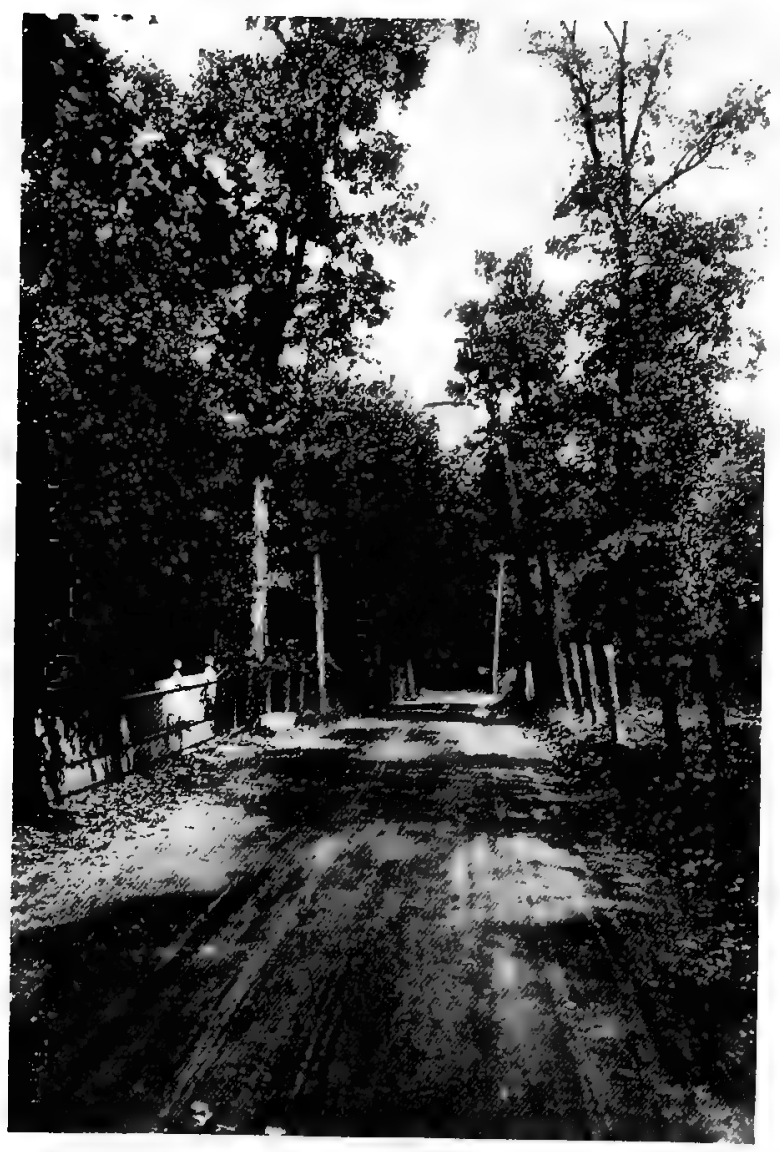

The Disappearing Road 


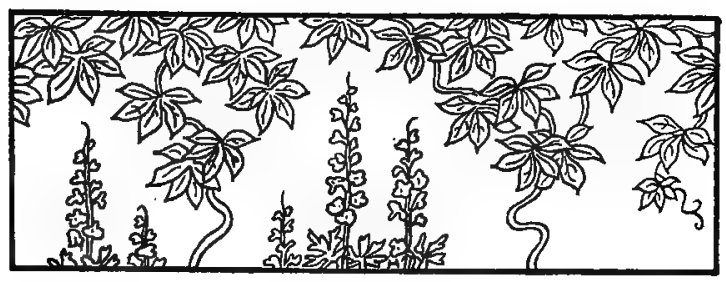

\section{CHAPTER XIV \\ A Farewell "Hike"}

7 HIS morning I got into my 1 "knickers" and a good stout pair of army shoes and took the road. It was Saturday, too, and the golf links looked inviting enough, but the season was rapidly coming to an end, and I preferred a tramp outside, because I knew that within a week we would be back in town where I was certain to be uncomfortable for a time among the crowds after having been so long in the open country. The air was soft and cool, the sun just bright enough and the fields and hills and distant points were sleeping in an atmosphere that told the story old, yet ever new, of summer gone. A note of universal gladness [ 189] 


\section{The Black Swans}

attends the April shower. A sense of peace and plenty fills the spirit when the wheat and oat fields and the meadows yield their harvests, but today the rustling corn blades and the brown and silent wood-lands speak soothingly of rest and sleep and finished tasks.

I had not gone far before I overtook an old friend of mine whose business this particular day was evidently the same as my own-the draining of the few remaining drops still hanging upon the lips of a season's emptied cup. I found him busy with a bunch of goldenrod that had survived most of its companions of the roadside and was still fresh and full of life. I stopped and watched the busy gleaner at his belated work. I fancy he was thinking that the sweet clovers of August were rather better producers for his particular purpose, but his persistence apparently met with some reward, and presently he spread his wings. 


\section{A Farewell "Hike"}

A little farther on some bumble bees were on a thistle bloom, and sitting down besides the humble plant that seemed to have extracted honey by some subtle process from a stiff clay soil, I held the stems within my hand and with a glass observed the searching quest for food. The head of a bumble bee is not in general shape unlike that of an elephant's, and the comparison does not altogether end with that, for it has a proboscis of some sort that finds its way deep down into the minute recesses of each pink thistle tube. No possible opening escapes their probe. They did not mind me in the least of course. When a boy I used to kill them, and pulling their bodies in half would extract the honey sac and found it sweet. But I have more respect now for life in any form, and did not resume my tramp until this industrious black-and-yellow trio had lazily taken themselves off to some other lingering way-side growth. 


\section{The Black Swans}

We now approach, a pasture. The grazing still is good, and in a corner near the road a group of dairy cows, some standing, some lying down, chew their cud complacently, and turn big eyes and ears my way as I come near. They are mostly Jersey grades and friendly. I stop and visit with them for a time. One of the younger set in particular seems sociably inclined. She comes up to the fence, and I speak to her. She may be of the pure blood. Her fawn-like features show some breeding at any rate, and her shapely udder and well-placed appendages thereto are full of promise. Is it any wonder people become attached to and fond of well-bred animals? As old Jorrocks of fox-hunting fame used to say, "Give me a bit of blood, whether it be in a 'orse, a 'ound or a woman!" Surely it tells. Across the way there is another bunch of cattle of the genus "scrub." Poor things! They are not to blame for their own 


\section{A Farewell "Hike"}

wretched personalities and very limited capacities, but what good farmer would wish to board them or see them about the place? And what boy growing up in their company could ever develop a genuine fondness for the farm? They neither appeal to your affections nor make any good return for the valuable food they eat. But look into the intelligent, friendly eyes of this little Jersey, with her graceful horns, her yellow skin and silky coat, her dainty limbs and swelling milk veins, and behold one of the accomplishments of man in fixing fast in animal form the useful and the beautiful.

It has been many a moon since I milked my quota of an old-time herd, but there is worse employment in this world, as I now know. Even yet it seems to me I hear the cow bells in the lower pasture as the cattle work their way at close of day up towards the gate; for they, like the rest of us, are creatures of habit; and I recall 


\section{The Black Swans}

that in the winter time each individual member of the herd knew her own particular stall inside the barn, and rarely made mistake in seeking it. Each knew that a bed of clean, dry straw had been prepared before they entered for the night, and that all troughs and mangers were well-filled and waiting. And when the storm went driving by as a bitter night came on and the big bare trees along the creek were lashed and coated with the driving snow or sleet, and I had gone to bed, how satisfied I used to feel to know that those four-footed friends were warm and snug inside and did not want!

I am sorry I cannot say that I saw very many well-bred animals this day of my October gypsying along this country road. It is a district populated mainly by folk of German birth or blood, and whatever of thrift or other virtues they may possess, an appreciation of improved varieties of domestic 


\section{A Farewell "Hike"}

animals does not seem to exist to any great extent among them. With all her boasted efficiency and "Kultur," Germany has yet to give the world anything much worth while in the realm of animal husbandry, as compared with her neighbors of Belgium, France, the Netherlands, the Channel Islands or Great Britain. I did see now and then a horse that might have had a Percheron sire, but these were few and far between. And this reminds me of another country road I traveled once in sunny France in the charming little valley of the Huisne (pronounced "Ween") where whitewalled cottages and cosy little homes with gardens filled with wondrous flowers and sweet old-fashioned roses bloomed, and apple blossoms spread their fragance far and wide just as they do in Normandy. In all the world there are no greater pets than those big fine mares and foals attended in that favored land by the women and

$$
\text { [ } 195 \text { ] }
$$




\section{The Black Swans}

the children of each household. Is it any wonder, these big honest black and gray horses of heavy draft that you see in daily use upon our city streets and cornbelt farms, are as gentle as so many well-trained dogs, that almost any child can handle them? We are in France's debt for many things, and not the least of these is the great horse that is such a factor in the moving of the nation's plows and heavy trucks. You would not of course expect to see the Percherons numerous in a Bremen township. You will see geese though and horses of which you could not be very proud, and sometimes women, too, that are old before their time and overworked. But it is time we were on the homeward trail.

I have been resting as I have thus been soliloquizing beneath a venerable cottonwood that stands at the end of a row evidently planted by an early settler in these parts. These are of 


\section{A Farewell "Hike"}

course quick-growing trees. How long they live I do not know, but this one of which I speak is not to hear its leaves rattling in this southwest wind for many seasons more. It is a giant of its sort; I should say near ten feet in circumference. That is conceding a diameter at its base of around three feet. Its main top branch has been lost in some gale years ago. It stands thus crippled and decaying in its gray old age awaiting, like any other living thing that has had its great day on earth, the end of everything. A decrepit wretch in human form, probably from the county poorfarm over there on the other road, went by a few moments ago, and I classed them together and knew that the fate of both differs in no wise from that which is overtaking a brown dustcovered grasshopper that just jumped feebly by me on the grass.

And so we draw near home. Not far from where the black swans nestle 


\section{The Black Swans}

on the hearth there is this late fall day a spot that has for me an infinitely greater charm than any picture gallery of which this world can boast. It is a patch of woodland that men have not yet touched. Briars and burrs and thickly-matted bluegrass contest with all sorts of underbrush for possession of the soil beneath the trees. You will have to fight your way into this tangled hidden sanctuary, but once inside you will feel and know that you are a part of all of it, and the gray clouds floating away there towards the lake shall pass on over the great city with all its miseries and leave you to your thoughts and prayers and the blessed solace of close fellowship with Nature clad in beauty that no human hand can imitate nor words describe. Wild grapes and woodbine help themselves to the first supporting branch they find. Here and there the burly bodies of great oaks speak eloquently of strength and patient, silent growth through the un- 


\section{A Farewell "Hike"}

counted dawns and sunsets of the passing years. Through the tree tops a glimpse of sky, part blue, part gray, and all around the soft rich tints of woodland tapestries woven in colors only found in Nature's northern arboreal laboratories. The intangible gradations from green to brown, rose-pink to richest crimson, from pale lemon to deep orange, defy definition or interpretation. And tomorrow other tints will show.

As I now return to the cottage walk, a squirrel frisks by on his way to the big trees in the grove. Acorns have been falling fast for many days upon the lawn. One of our trees in particular seems to have produced this year most bountifully. And today we made a great discovery. Just opposite our bed-room window we had long ago fastened a little so-called "wrenhouse" to one of the biggest burr-oak limbs. For some reason or other the birds had never used it. I imagine 


\section{The Black Swans}

because they figured that predatory cats or squirrels might reach it too easily. The opening in this tiny house was very small. We had observed, however, that some creature of the wild had been busy of late enlarging the entrance. We had never had the good fortune to catch any of these woodmen at the task; so were uncertain about the scheme in view. Anyhow some one had now crammed that little box full to overflowing with acorns, against some day of need, and we of course credit this bit of real preparedness to the squirrels. None of them live in the trees about the house, but if the coming winter should prove as hard as was the last, this extra store might very acceptably supplement the main larder located deeper in the woods. So much by way of a lesson from these little folk in the matter of saving while the saving's good.

All day long I have seen flitting through the trees small birds innumer- 


\section{A Farewell "Hike"}

able that do not spend their summers here. I do not profess to know their names. They are from the north and tomorrow will be farther south. The annual migration is at its height, and we ourselves are joining in it. Those fat bronze turkeys foraging contentedly among the corn shocks would migrate too if they were wise.

I took back with me at the close of this really perfect day the last of our dark-blue larkspurs, decorated with a lacy spray of woodbine, the fiveleaved clusters of which were almost as brilliant as Poinsettias at Christmas time. And that was the last floral offering I was able to bring this year to the household gods.

The darkness settles early, and as the night is cloudless I improve the opportunity, before settling down to a final session with the fire, to bid the bright October sky good-bye. I know perfectly well that when we begin driving up and down the city boule-

$$
\text { [ 20I ] }
$$




\section{The Black Swans}

vards, when the electric lights are on, there will be little use trying to visit even with the Big Dipper itself, saying nothing about Cassiopeia. And so I pass out into the open beyond the gateway through the hedge. Low in the east old Orion is rising. Andromeda is glowing over-head and in the west my steel-blue favorite Vega! Stars of the quiet autumn night! Changeless and steadfast as thy fires shall be my love for dear old Dumbiedykes and all its treasured memories.

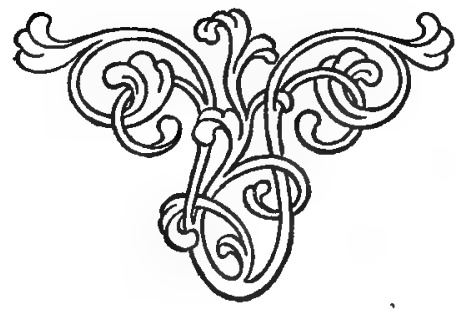




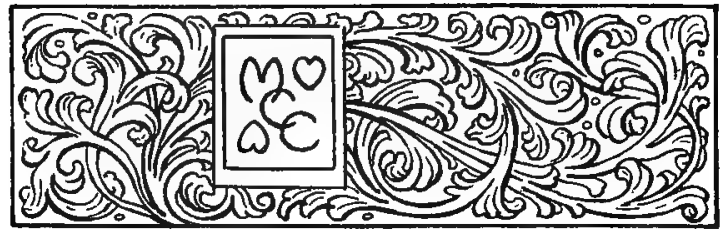

\section{CHAPTER XV}

\section{Taps}

$7 \mathrm{HE}$ last fire of another year is 1 dying on the hearth. The swans are flying low-now very low-and presently they will fold their fluttering wings and pass into the shadows that shall last until the fires of yet another spring shall be rekindled by our own or other hands. 'Tis said the sweetest of all songs sung by swans are always their very last, and, as our walls reflect the gathering gloom, in fancy I can hear what seems to be a fond farewell to all the joys the vanished hours have brought.

We are closing the cottage tomorrow. It is the end of our sixteenth season within its walls. Somehow the little [ 203] 


\section{The Black Swans}

place has grown to be a part of life itself. We have banked the fire and locked the entrance gate and left the old clock standing there alone each fall with ever-deepening regret, because each time has brought the thought that this may be the last.

We always trust we may come back again to see the hedge-rows and the iris wake, but maybe we shall not. The cricket that until tonight has chirped about the hearth is gone. The frost has sapped all floral life outside. Above the general wreck a drooping salvia only shows its scarlet bloom, but it too, like Omar's Bird of Time, "has but a little way to go." All things come to an end at last, even the most idyllic days in rare sequestered nooks. Conditions change, and circumstances; and we change with them. Turns come at length in every path.

The spring-time and the summer of our days at Dumbiedykes have passed. That much is sure. The autumn now 


\section{Taps}

is here, and the same unchanging laws that govern in the garden and the grove apply as well to those who plant and plan. A few short weeks ago the lawn was clean and green, well-trimmed and comely: Tonight it is strewn with the oak leaves of accomplished fact. There is no longer quick response to the discharging clouds. The sun has lost its power. The green has turned to gold. The gold is on its way to dust. The last log on the hearth is turning now to ash. The hands of the clock still move forever forward; never back. There is no force in earth or air, no alchemy in sky or cloud, can stay the year's decline.

Would that we might live those years again! There has been much that has -been truly bright and beautiful, and many golden hours have set an impress on our hearts which time shall not efface. And yet there have been roses set that never flowered, and weeds and thorns have come sometimes where 


\section{The Black Swans}

finer growths were sought. There have been shadows dark, and bats and fearsome cries of owls, as well as happy May-time songs in leafy bowers. Which is to say that this, our life at Dumbiedykes, has simply been the world-old blend of sunshine and of storm.

October's mellow haze has come. The winter waits. We know not what it has in store. Some time, somewhere, perhaps around the evening lamp, when north winds howl around your Dumbiedykes or mine, when thoughts of springs and summers past shall only be as happy dreams that linger long in memory, perchance we'll meet again.

And so we will not say "Farewell," but just "Good night."

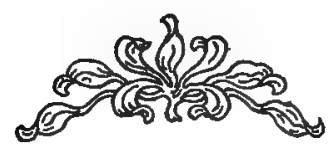


PRINTED BY R. R. DONNELLEY AND SONS COMPANY AT THE

LAKESIDE PRESS, CHICAGO, ILL. 






